\title{
Identification of Active Species in Photodegradation of Aqueous Imidacloprid over $\mathrm{g}-\mathrm{C}_{3} \mathrm{~N}_{4} / \mathrm{TiO}_{2}$ Nanocomposites
}

\author{
Thawanrat Kobkeatthawin ${ }^{1}$, Jirawat Trakulmututa ${ }^{1}$, Taweechai Amornsakchai ${ }^{1}$, Puangrat Kajitvichyanukul ${ }^{2, *}$ \\ and Siwaporn Meejoo Smith $1, *$ (D)
}

check for

updates

Citation: Kobkeatthawin, T.;

Trakulmututa, J.; Amornsakchai, T.;

Kajitvichyanukul, P.; Smith, S.M.

Identification of Active Species in

Photodegradation of Aqueous

Imidacloprid over g- $\mathrm{C}_{3} \mathrm{~N}_{4} / \mathrm{TiO}_{2}$

Nanocomposites. Catalysts 2022, 12,

120. https://doi.org/10.3390/

catal12020120

Academic Editors: Ioan Balint and

Monica Pavel

Received: 23 December 2021

Accepted: 16 January 2022

Published: 19 January 2022

Publisher's Note: MDPI stays neutral with regard to jurisdictional claims in published maps and institutional affiliations.

Copyright: () 2022 by the authors Licensee MDPI, Basel, Switzerland. This article is an open access article distributed under the terms and conditions of the Creative Commons Attribution (CC BY) license (https:/ / creativecommons.org/licenses/by/ $4.0 /)$.
1 Center of Sustainable Energy and Green Materials and Department of Chemistry, Faculty of Science, Mahidol University, 999 Phuttamonthon Sai 4 Rd, Salaya 73170, Thailand; kunthidakob@gmail.com (T.K.); jirawat.trk@student.mahidol.edu (J.T.); taweechai.amo@mahidol.edu (T.A.)

2 Department of Environmental Engineering, Faculty of Engineering, Chiang Mai University 239, Huay Kaew Road, Muang District, Chiang Mai 50200, Thailand

* Correspondence: puangrat.k@cmu.ac.th (P.K.); siwaporn.smi@mahidol.edu (S.M.S.)

\begin{abstract}
In this work, $\mathrm{g}-\mathrm{C}_{3} \mathrm{~N}_{4} / \mathrm{TiO}_{2}$ composites were fabricated through a hydrothermal method for the efficient photocatalytic degradation of imidacloprid (IMI) pesticide. The composites were fabricated at varying loading of sonochemically exfoliated $\mathrm{g}-\mathrm{C}_{3} \mathrm{~N}_{4}$ (denoted as CNS). Complementary characterization results indicate that the heterojunction between the $\mathrm{CNS}$ and $\mathrm{TiO}_{2}$ formed. Among the composites, the $0.5 \mathrm{CNS} / \mathrm{TiO}_{2}$ material gave the highest photocatalytic activity $(93 \%$ IMI removal efficiency) under UV-Vis light irradiation, which was 2.2 times over the pristine $\mathrm{g}-\mathrm{C}_{3} \mathrm{~N}_{4}$. The high photocatalytic activity of the $\mathrm{g}-\mathrm{C}_{3} \mathrm{~N}_{4} / \mathrm{TiO}_{2}$ composites could be ascribed to the band gap energy reduction and suppression of photo-induced charge carrier recombination on both $\mathrm{TiO}_{2}$ and CNS surfaces. In addition, it was found that the active species involved in the photodegradation process are $\mathrm{OH} \bullet$ and holes, and a possible mechanism was proposed. The $\mathrm{g}-\mathrm{C}_{3} \mathrm{~N}_{4} / \mathrm{TiO}_{2}$ photocatalysts exhibited stable photocatalytic performance after regeneration, which shows that $\mathrm{g}-\mathrm{C}_{3} \mathrm{~N}_{4} / \mathrm{TiO}_{2}$ is a promising material for the photodegradation of imidacloprid pesticide in wastewater.
\end{abstract}

Keywords: imidacloprid (IMI); graphitic carbon nitride $\left(\mathrm{g}-\mathrm{C}_{3} \mathrm{~N}_{4}\right)$; titanium dioxide $\left(\mathrm{TiO}_{2}\right) ; \mathrm{g}-\mathrm{C}_{3} \mathrm{~N}_{4} / \mathrm{TiO}_{2}$ composite; photocatalytic activity

\section{Introduction}

Imidacloprid (IMI), which is the most widely used pesticide in the group of neonicotinoids, is a pesticide that is used in agriculture such as in crop protection against aphids, leafhoppers, psyllids beetles, etc. [1], and parasite management [2]. The use of neonicotinoids has been registered in approximately 120 countries worldwide [3], and IMI is one of the top ten global agrochemicals used as a pesticide worldwide [4]. It acts as a nicotinic acetylcholine receptor (nAChR) agonist that interferes with the transmission in the central nervous system of insects and results in paralysis and death [5]. With their widespread use, persistent nature, and high solubility $\left(610 \mathrm{mg} / \mathrm{L}\right.$ in $20{ }^{\circ} \mathrm{C} \mathrm{H}_{2} \mathrm{O}$; $\left.\log \mathrm{K}_{\mathrm{ow}}=0.57\right)$, IMI can cause damage to the environment via transportation in water, soil, and air [6]. Furthermore, the use of IMI can affect human health which includes neurological effects $[7,8]$, in addition to gastrointestinal symptoms, lethargy [9], emaciation thyroid lesions, and cardiorespiratory failure [10]. Thus, the removal of these pollutants from water is essential due to their harmful influence on human health and aquatic ecosystems. Various methods can be applied for the degradation of IMI from aqueous solutions such as microfiltration membrane [11], biological degradation [12], adsorption [13,14], and advanced oxidation processes (AOPs) [15,16]. Among the AOP methods, photocatalytic activity has been used effectively in wastewater treatment for the removal of organic pollutants due to its simplicity, high activity, low cost, and ability to reduce $\mathrm{CO}_{2}[17,18]$. 
Graphitic carbon nitride $\left(\mathrm{g}-\mathrm{C}_{3} \mathrm{~N}_{4}\right)$ has attracted significant attention as a visible photocatalyst for water purification due to its stability, high surface area, eco-friendliness, and facile synthesis $[19,20]$. However, the disadvantage of pure $\mathrm{g}-\mathrm{C}_{3} \mathrm{~N}_{4}$ is the fast recombination of photogenerated electron-hole pairs which lead to low photocatalytic efficiency [21]. Many strategies have been tried to improve the photocatalytic performance such as nanostructure design [22,23], metal and non-metal doping [24], and composite photocatalysts [25-28]. Among the various strategies, photocatalysis by coupling with other semiconductor materials is a beneficial method to improve the electron recombination process and extend the visible light absorption, which can enhance the photocatalytic performance. $\mathrm{TiO}_{2}$ is an n-type semiconductor that has been widely used owing to the high efficiency, low cost, non-toxicity, and long-term stability of this compound. However, because of the large band gap energy of $3.2 \mathrm{eV}$ of $\mathrm{TiO}_{2}$, this results in the ineffective utilization of visible light, low quantum efficiency, and fast recombination [29]. It is expected that coupling $\mathrm{TiO}_{2}$ with $\mathrm{g}-\mathrm{C}_{3} \mathrm{~N}_{4}$ can improve electron-hole pair recombination, broaden the photo-response range, and promote oxidation and reduction processes.

Herein, g- $\mathrm{C}_{3} \mathrm{~N}_{4} / \mathrm{TiO}_{2}$ photocatalysts were synthesized by a simple hydrothermal method. The phase structure, chemical composition, morphology, and scavenger trapping were investigated in detail. The g- $\mathrm{C}_{3} \mathrm{~N}_{4} / \mathrm{TiO}_{2}$ photocatalysts were used to degrade imidacloprid pesticide in wastewater under UV-Vis light irradiation. The recyclability of the composite was studied. In addition, the possible photodegradation mechanism was also proposed in this study.

\section{Results and Discussion}

\subsection{Characterization}

The XRD patterns of bulk-CN, CNS, $\mathrm{TiO}_{2}$, and $0.5 \mathrm{TiO}_{2} / \mathrm{g}-\mathrm{C}_{3} \mathrm{~N}_{4}$ are shown in Figure 1a. The $\mathrm{g}-\mathrm{C}_{3} \mathrm{~N}_{4}$ has two main diffraction peaks at $13.1^{\circ}$ and $27.5^{\circ}$, which corresponds to the (001) plane caused by the arrangement of the tri-s-triazine units and the (002) plane caused by the interlayer stacking of the conjugated aromatic ring (JCPDS 87-1526) [29]. After the exfoliation of the bulk-CN, the decrease of CNS intensity (002) peak indicated that the interlayer structure was partially destroyed [30,31], and the slight shift of the (002) peak is attributed to the decreased distance of the basic sheets in the nanosheets [32]. The peaks of pure $\mathrm{TiO}_{2}$ at $25.3,37.8,48.0,53.9,62.7,68.8,70.3,75.0$, and $82.6^{\circ}$ correspond to the (101), (004), (200), (211), (204), (116), (220), (215), and (224) crystal planes of anatase $\mathrm{TiO}_{2}$ (JCPDS 21-1272) [33]. Hydrothermally synthesized g- $\mathrm{C}_{3} \mathrm{~N}_{4} / \mathrm{TiO}_{2}$ photocatalysts showed the patterns related to both pure g- $\mathrm{C}_{3} \mathrm{~N}_{4}$ and $\mathrm{TiO}_{2}$. In addition, there is no obvious change in the peaks of $\mathrm{TiO}_{2}$ in the composites, indicating that coupling with $\mathrm{g}-\mathrm{C}_{3} \mathrm{~N}_{4}$ did not influence the phase structure of $\mathrm{TiO}_{2}$.

The Raman spectra of $\mathrm{g}-\mathrm{C}_{3} \mathrm{~N}_{4}, \mathrm{TiO}_{2}$, and $\mathrm{g}-\mathrm{C}_{3} \mathrm{~N}_{4} / \mathrm{TiO}_{2}$ composites are shown in Figure $1 \mathrm{~b}$. The characteristic peaks of $\mathrm{g}_{-} \mathrm{C}_{3} \mathrm{~N}_{4}$ appeared at $707 \mathrm{~cm}^{-1}$ and $1230 \mathrm{~cm}^{-1}$ which were assigned to the breathing modes of the tri-s-triazine ring and $\mathrm{C}-\mathrm{N}$ heterocycles, respectively [34]. Moreover, all the Raman bands observed for bulk-CN can be found in the CNS. The Raman spectrum of pure $\mathrm{TiO}_{2}$ exhibited peaks at $148,395,510$, and $640 \mathrm{~cm}^{-1}$ corresponding to anatase-phase $\mathrm{TiO}_{2}$ [35]. $15 \mathrm{CNS} / \mathrm{TiO}_{2}$ showed a combination peak of g$\mathrm{C}_{3} \mathrm{~N}_{4}$ and $\mathrm{TiO}_{2}$ which confirms the formation of composites. No peak shifts were observed, which means no structural changes occurred during the preparation of the composites with pure $\mathrm{TiO}_{2}$ and $\mathrm{g}-\mathrm{C}_{3} \mathrm{~N}_{4}$. 

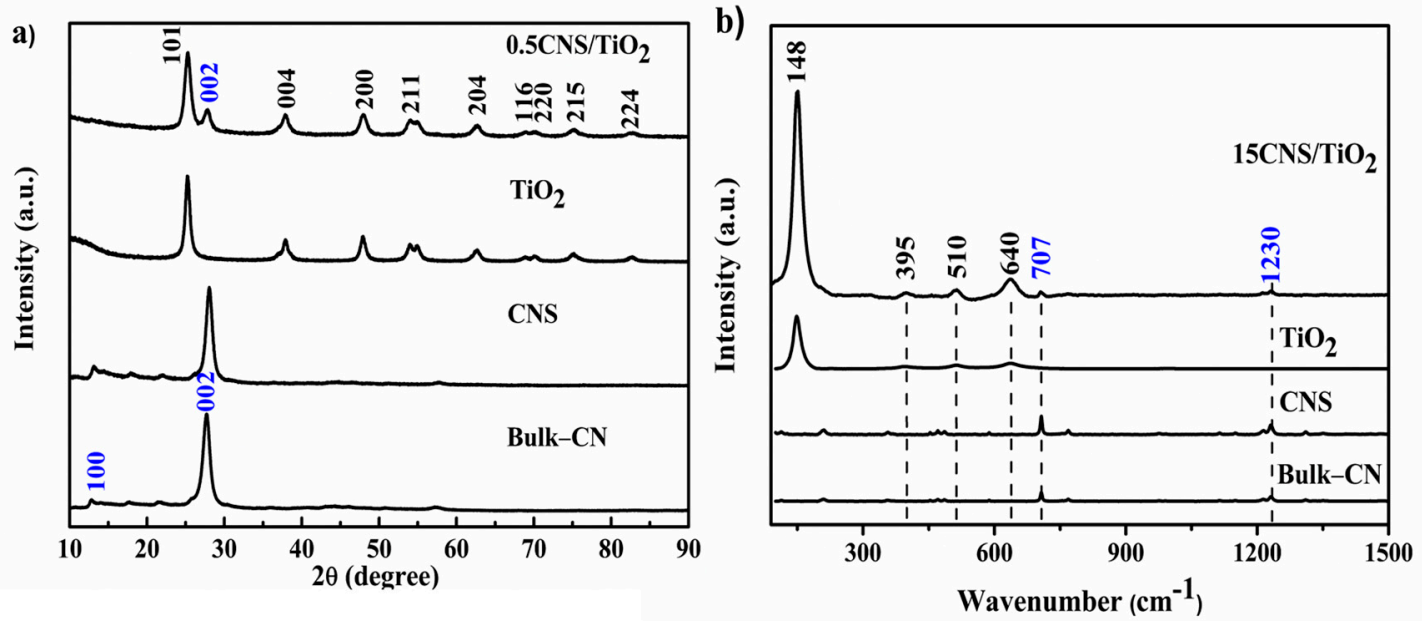

Figure 1. (a) Powder XRD patterns of bulk-CN, CNS, $\mathrm{TiO}_{2}$, and $0.5 \mathrm{CNS} / \mathrm{TiO}_{2}$. (b) Raman spectra of bulk-CN, CNS, $\mathrm{TiO}_{2}$, and $15 \mathrm{CNS} / \mathrm{TiO}_{2}$. Figure $\mathrm{S} 1$ shows the PXRD of the rest of nanocomposites.

The chemical binding states of $\mathrm{g}-\mathrm{C}_{3} \mathrm{~N}_{4}, \mathrm{TiO}_{2}$, and composites were studied through XPS analysis. Figure 2a displays the survey scan of bulk-CN, CNS, $\mathrm{TiO}_{2}$, and g- $\mathrm{C}_{3} \mathrm{~N}_{4} / \mathrm{TiO}_{2}$ in various weight ratios which confirmed the presence of $\mathrm{C}, \mathrm{N}, \mathrm{Ti}$, and $\mathrm{O}$ atoms in the composites. Figure $2 \mathrm{~b}$ shows three high-resolution $\mathrm{C} 1 \mathrm{~s}$ spectrums at binding energies of 285.0, 288.3, and $289.2 \mathrm{eV}$, assigned as $\mathrm{C}-\mathrm{C}, \mathrm{N}-\mathrm{C}=\mathrm{N}$, and $\mathrm{sp}^{2}$ hybridized carbon in the tri-s-triazine ring $\left(\mathrm{N}_{2}-\mathrm{C}=\mathrm{N}\right)$ for $\mathrm{g}-\mathrm{C}_{3} \mathrm{~N}_{4}$.

Four binding energies in N 1s spectra (Figure 2c) can be observed, which can be classified into to $\mathrm{sp}^{2}$ hybridized nitrogen $\mathrm{C}-\mathrm{N}=\mathrm{C}(398.8 \mathrm{eV})$, tertiary nitrogen $\mathrm{N}-(\mathrm{C})_{3}(399.2 \mathrm{eV})$, amino functional groups $\mathrm{N}-\mathrm{H}(400.3 \mathrm{eV})$, and $\pi$-excitation $(401.2 \mathrm{eV})$, respectively [36-38]. The $C 1$ s and $N 1$ s spectra are slightly shifted from primitive $g-C_{3} N_{4}$ which suggests that there is a chemical bond connection between $\mathrm{g}_{-} \mathrm{C}_{3} \mathrm{~N}_{4}$ and $\mathrm{TiO}_{2}$ [39]. The $\mathrm{C} / \mathrm{N}$ ratio of g- $\mathrm{C}_{3} \mathrm{~N}_{4}$ is 0.90 , indicating the presence of nitrogen vacancies that probably occurred during the thermal reduction process [40]. EPR spectra can provide evidence for probing the surface vacancies in photocatalysts. As shown in Figure 2f, the EPR intensity signal of CNS is significantly enhanced, revealing the increase of nitrogen vacancies generated in $\mathrm{gC}_{3} \mathrm{~N}_{4}$ [41]. Figure $2 \mathrm{~d}$ shows the high-resolution Ti $2 \mathrm{p}$ spectrum. The binding energy peaks of Ti $2 \mathrm{p}^{3 / 2}$ and Ti $2 \mathrm{p}^{1 / 2}$ appeared at 459.3 and $465.0 \mathrm{eV}$, which represent $\mathrm{Ti}^{4+}$ species in the form of $\mathrm{TiO}_{2}$ clusters [42]. In addition, there might be another Ti species in the material due to the poor XPS peak fitting for the $\mathrm{Ti}^{4+}$ alone. A better XPS profile fitting was later obtained by including a peak at $460.2 \mathrm{eV}$, being assigned as the $\mathrm{Ti}^{3+}$ defects on the composite surface $[43,44]$. The $\mathrm{O} 1 \mathrm{~s}$ spectrum in Figure 2e can be devised into three peaks in $\mathrm{TiO}_{2}$ with the binding energy of $530.5,531.9$, and $533.2 \mathrm{eV}$ which can be assigned to (Ti-O), oxygen vacancy $\left(\mathrm{V}_{\mathrm{o}}\right)$, and water molecules adsorbed on the surface of $\mathrm{TiO}_{2}$, respectively [45]. Figure $2 \mathrm{f}$ shows the result of the solid ESR measurement which was used to confirm the presence of $\mathrm{Ti}^{3+}$. A strong EPR signal of $\mathrm{TiO}_{2}$ and the composites was observed with $g$ of 1.997 , which corresponds with $\mathrm{Ti}^{3+}$ defect $\left(3 \mathrm{~d}^{1}, \mathrm{~S}=1 / 2\right)$ and oxygen vacancy (Vo) [46]. It is possible that $\mathrm{Ti}^{4+}$ was reduced to $\mathrm{Ti}^{3+}$ by the loss of oxygen from the surface of $\mathrm{TiO}_{2}$ because of the hydrothermal treatment at a high temperature [47]. 
a)

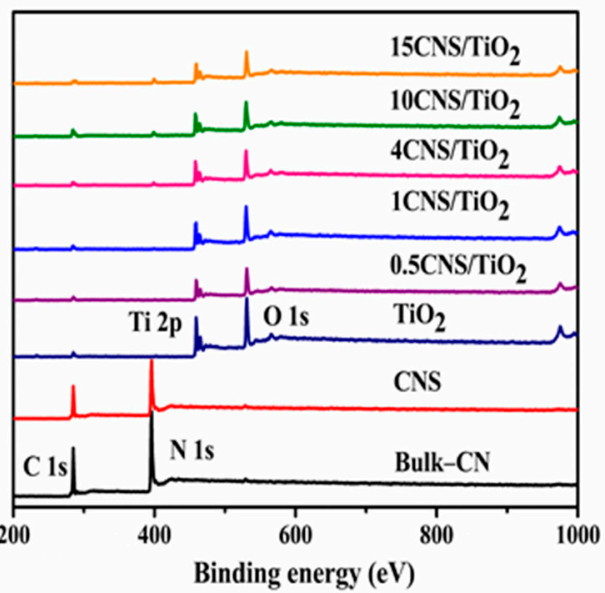

c)

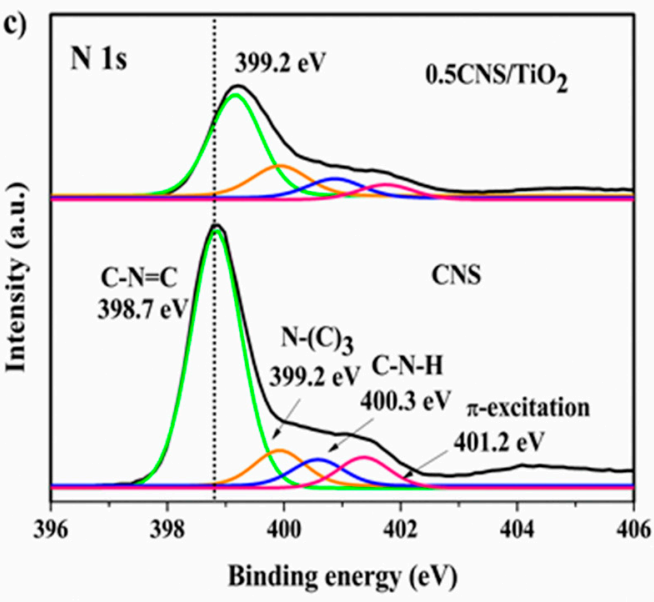

e)

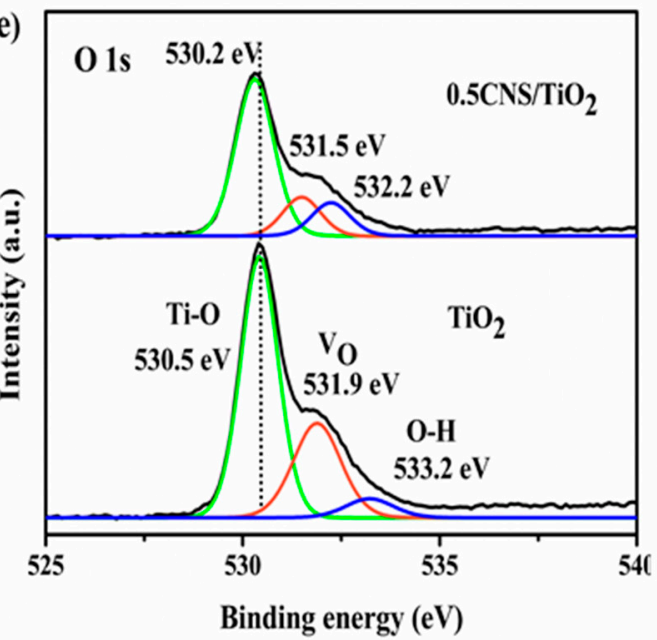

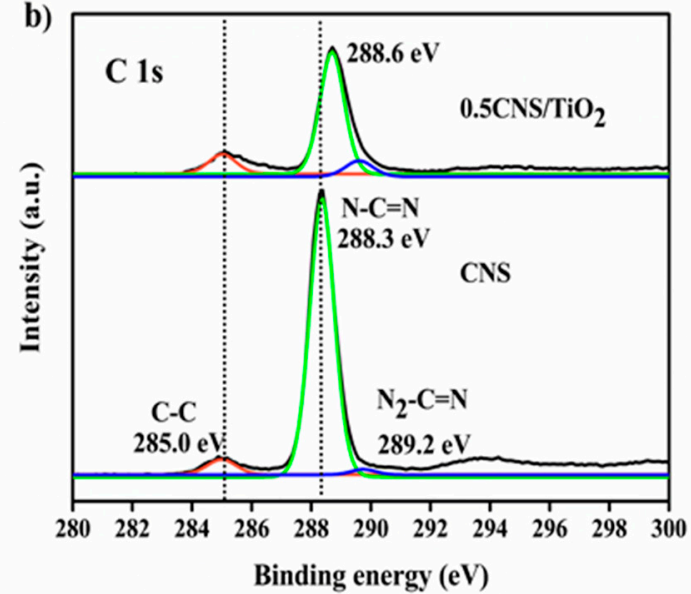
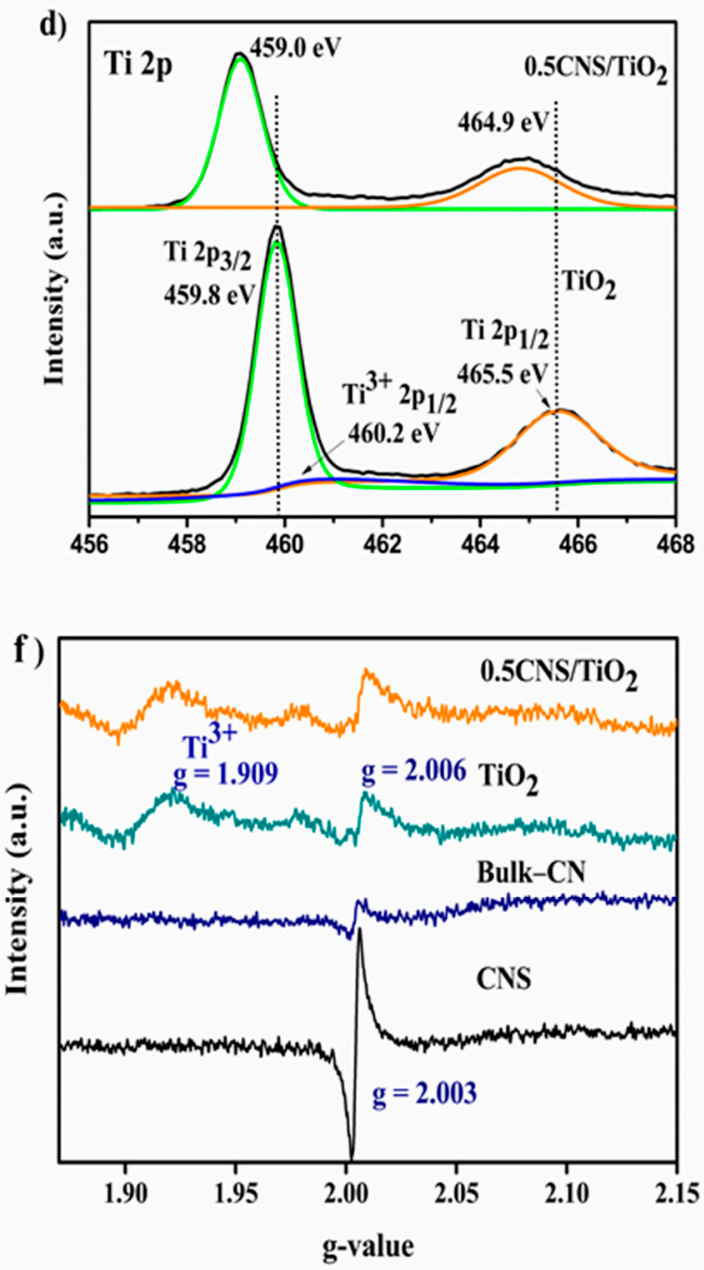

Figure 2. (a) The survey scan of all samples. (b) The C1s spectra. (c) The N1s spectra. (d) The Ti 2p spectra. (e) The O1s spectra. (f) Solid EPR spectra of g- $\mathrm{C}_{3} \mathrm{~N}_{4}, \mathrm{TiO}_{2}$, and g- $\mathrm{C}_{3} \mathrm{~N}_{4} / \mathrm{TiO}_{2}$.

\subsection{Morphology Study}

The morphologies of bulk-CN, CNS, $\mathrm{TiO}_{2}$, and $0.5 \mathrm{CNS} / \mathrm{TiO}_{2}$ composites were examined by SEM as shown in Figure 3. We can see that bulk-CN presents in the form of bulk morphology with a layered structure (Figure 3a) [48]. CNS revealed smaller particles like the nanosheet structure after thermal exfoliation with $\mathrm{HNO}_{3}{ }^{-}$(Figure 3b). The BET surface area of bulk-CN and CNS were calculated to be 68.26 and $91.61 \mathrm{~m}^{2} \mathrm{~g}^{-1}$, respectively. It is possible that the van der Waals forces and hydrogen bonds of $\mathrm{g}-\mathrm{C}_{3} \mathrm{~N}_{4}$ might be destroyed 
with thermal treatment which results in the separation of $g-C_{3} N_{4}$ into small layers $[49,50]$. In addition, nitric acid might be intercalated into interlayers of bulk-CN which caused the expansion of their interlayer space and reduction of the layer thickness and hence increased its surface area $[51,52]$. The obtained $\mathrm{TiO}_{2}$ showed spherical-like morphology with a particle size around $10 \mathrm{~nm}$. From Figure $3 \mathrm{~d}$, it can be seen that the CNS particles having thin-layered structures are well distributed on the surface of $\mathrm{TiO}_{2}$ particles, which is consistent with the presence of the peaks of $\mathrm{g}-\mathrm{C}_{3} \mathrm{~N}_{4}$ in XRD, XPS, and Raman spectra.
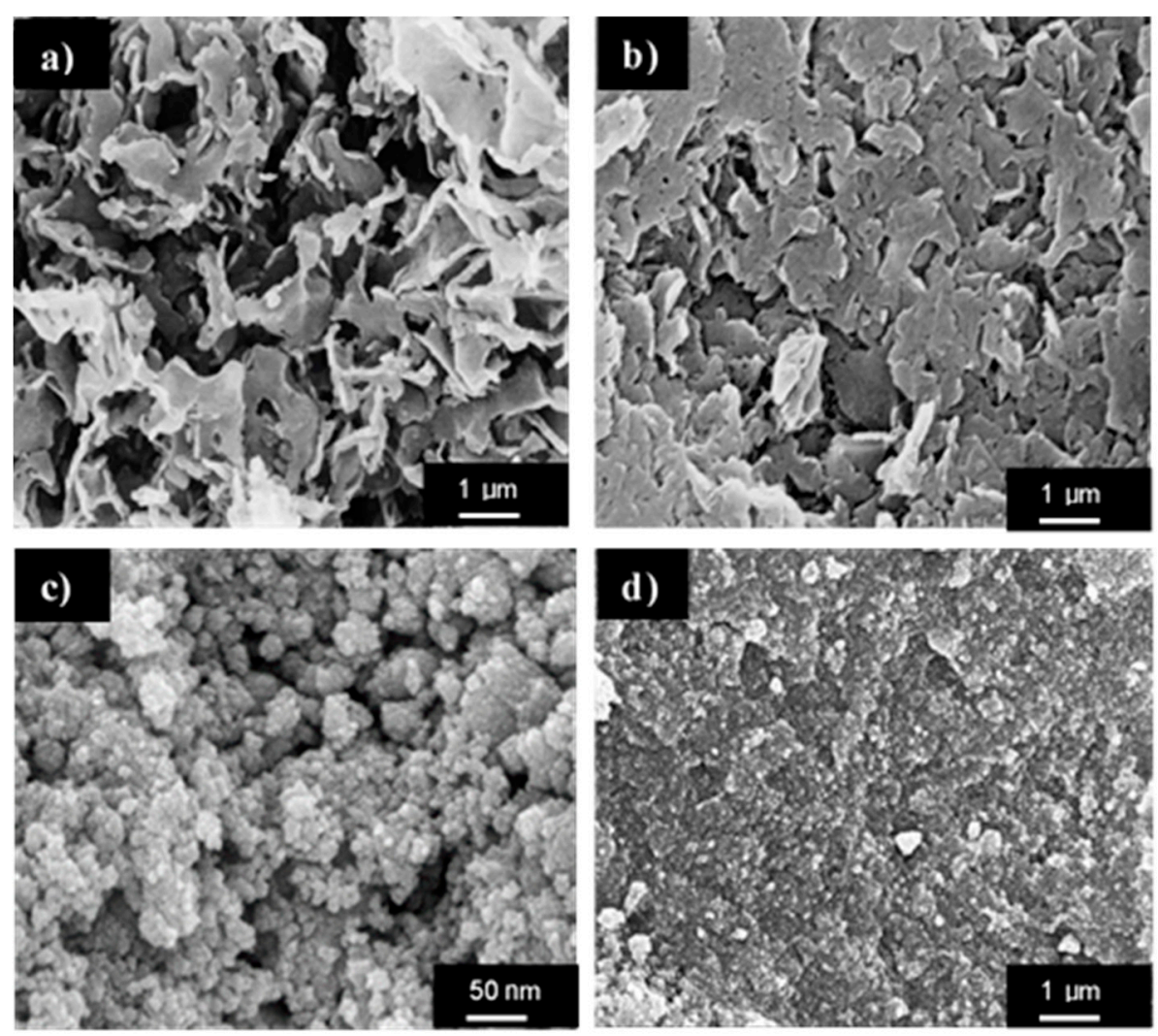

Figure 3. (a) SEM images of (a) bulk-CN, (b) CNS, (c) $\mathrm{TiO}_{2}$, and (d) $0.5 \mathrm{CNS} / \mathrm{TiO}_{2}$.

\subsection{Optical Study}

Figure 4 a shows the UV-Vis diffuse reflectance spectra of g- $\mathrm{C}_{3} \mathrm{~N}_{4}, \mathrm{TiO}_{2}$, and g- $\mathrm{C}_{3} \mathrm{~N}_{4} / \mathrm{TiO}_{2}$ composites. The exfoliated g- $\mathrm{C}_{3} \mathrm{~N}_{4}$ nanosheets show an absorption edge at $470 \mathrm{~nm}$ with a band gap of $2.93 \mathrm{eV}$, which was in agreement with previous reports [53]. The absorption spectra of the $\mathrm{TiO}_{2}$ shows an absorption edge at around $400 \mathrm{~nm}$ with a band gap of $3.20 \mathrm{eV}$. The presence of $\mathrm{g}-\mathrm{C}_{3} \mathrm{~N}_{4}$ resulted in the red shift of the absorption edge in all composites, revealing that the composites can be applied to visible-light photocatalysis. In addition, the presence of $\mathrm{Ti}^{3+}-\mathrm{TiO}_{2}$ can narrow the wide band gap of $\mathrm{TiO}_{2}$ for harvesting visible light and can provide an increase in electronic conductivity [54]. 

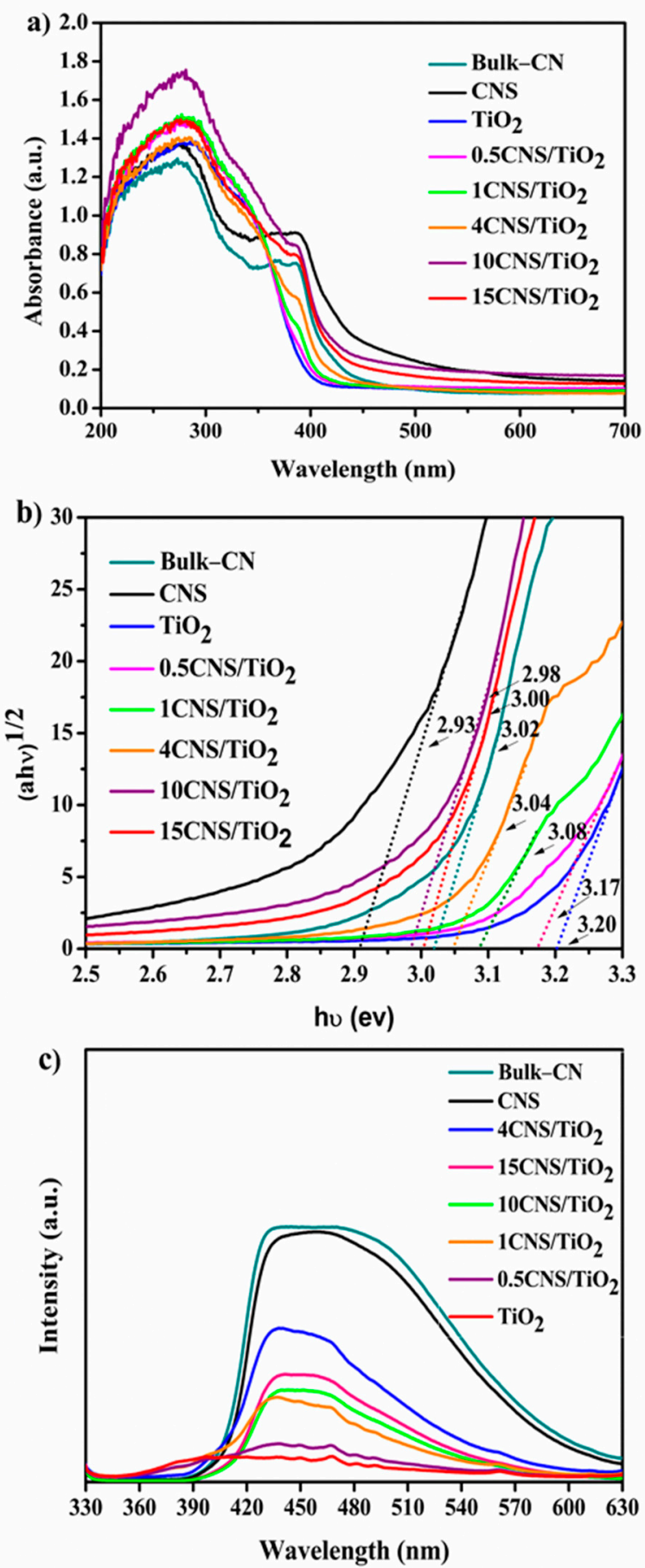

Figure 4. (a,b) UV-Vis DRS spectra and Tauc plot of $\mathrm{g}-\mathrm{C}_{3} \mathrm{~N}_{4}, \mathrm{TiO}_{2}$, and $\mathrm{g}-\mathrm{C}_{3} \mathrm{~N}_{4} / \mathrm{TiO}_{2}$ photocatalysts, (c) photoluminescence spectra of the as-synthesized g- $\mathrm{C}_{3} \mathrm{~N}_{4}, \mathrm{TiO}_{2}$, and $\mathrm{g}-\mathrm{C}_{3} \mathrm{~N}_{4} / \mathrm{TiO}_{2}$.

The band gap energy was calculated using the Tauc plot in Equation (1) and is shown in Figure 4b [55].

$$
\alpha \mathrm{h} v=\mathrm{A}(\mathrm{h} v-\mathrm{Eg})^{1 / 2}
$$

where $\alpha$ is the optical absorption coefficient, h is Planck's constant, $v$ is photon frequency, A is constant, and Eg is band gap.

The band gaps of pure $\mathrm{g}-\mathrm{C}_{3} \mathrm{~N}_{4}, \mathrm{TiO}_{2}$, and $0.5 \mathrm{CNS} / \mathrm{TiO}_{2}$ were calculated to be 2.93, 3.20 , and $3.17 \mathrm{eV}$, respectively. 
Photoluminescence analysis was performed in order to determine the electron-hole recombination which is shown in Figure 4c. Under excitation at $320 \mathrm{~nm}$, the emission peak of g- $\mathrm{C}_{3} \mathrm{~N}_{4}$ appears at around $457 \mathrm{~nm}$. The bulk-CN and CNS showed high PL intensity because of the fast recombination of electron-hole pairs, whereas $\mathrm{TiO}_{2}$ showed a broad emission peak at $410 \mathrm{~nm}$ and a lower maximum peak than that of the $\mathrm{g}-\mathrm{C}_{3} \mathrm{~N}_{4}$ system. After the hybridization of $\mathrm{g}-\mathrm{C}_{3} \mathrm{~N}_{4}$ and $\mathrm{TiO}_{2}$, the composite showed a much weaker emission peak, implying that the recombination of charge carriers may be effectively inhibited.

\subsection{Photocatalytic Study}

The photocatalytic performance of $\mathrm{g}-\mathrm{C}_{3} \mathrm{~N}_{4}, \mathrm{TiO}_{2}$, and composites was evaluated for IMI degradation under UV-Vis light irradiation in Figure 5. Photolysis of IMI degradation was carried out under the same conditions, as can be seen from Figure S2. It was found that the photolysis is not the main cause of effective degradation of IMI. On the other hand, the treatments of IMI with catalysts are less effective in dark conditions. From this result, the g- $\mathrm{C}_{3} \mathrm{~N}_{4}$ system exhibited low photocatalytic efficiency in the degradation of IMI. This could be because of the fast recombination of electron-hole pairs, as evidenced by PL spectra (Figure $4 \mathrm{c}$ ). However, it was found that exfoliated $\mathrm{g}-\mathrm{C}_{3} \mathrm{~N}_{4}$ showed higher photocatalytic activity than bulk-g- $\mathrm{C}_{3} \mathrm{~N}_{4}$. It could be explained as the effects of a larger specific surface area, narrow band gap, and nitrogen defects which improved photogenerated charge separation and transfer [56]. In addition, the incorporation of $\mathrm{TiO}_{2}$ clearly enhances the photocatalytic activity of $\mathrm{g}-\mathrm{C}_{3} \mathrm{~N}_{4}$. Specifically, $0.5 \mathrm{CNS} / \mathrm{TiO}_{2}$ and $1 \mathrm{CNS} / \mathrm{TiO}_{2}$ exhibited excellent photocatalytic activity, and photocatalysts were able to degrade $93.1 \%$ and $88.3 \%$ of IMI within 150 min, while pure $\mathrm{TiO}_{2}$ and $\mathrm{g}-\mathrm{C}_{3} \mathrm{~N}_{4}$ only degraded IMI by $79.7 \%$ and $51.8 \%$, respectively. It is reasonable that there might have been a synergetic effect between $\mathrm{TiO}_{2}$ and $\mathrm{g}-\mathrm{C}_{3} \mathrm{~N}_{4} \cdot \mathrm{g}-\mathrm{C}_{3} \mathrm{~N}_{4}$ can narrow the band gap energy and increase solar absorption efficiency. In addition, $\mathrm{Ti}^{3+}$ and oxygen vacancies $(\mathrm{Ov})$ in $\mathrm{TiO}_{2}$ can suppress the recombination of photogenerated electron-hole pairs and promote charge separation [57] which led to high photocatalytic degradation of IMI. As seen in Figure 4c, CNS gave a very broad PL spectrum having a very high intensity. In addition, the PL intensity from $0.5 \mathrm{CNS} / \mathrm{TiO}_{2}$ was found just slightly higher than that from the $\mathrm{TiO}_{2}$ material (much weaker than that of $\mathrm{CNS}$ ). Several works $[58,59]$ related the intensity of PL spectra to the oxidation-reduction potential between the conduction band and the valence band. PL spectra with lower intensity described a low probability of photogenerated electron-hole recombination. Although PL results suggest a slightly faster recombination rate on the $0.5 \mathrm{CNS} / \mathrm{TiO}_{2}$, its relatively narrow band gap (compared with $\mathrm{TiO}_{2}$ ) promoted superior IMI removal efficiencies (Figure 5). It should be noted that the loading level of $\mathrm{g}-\mathrm{C}_{3} \mathrm{~N}_{4}$ played an important role in improving the IMI photodegradation. It was found that the photocatalytic rate of activity slightly decreased after 90 min irradiation time when the loading of $g-C_{3} \mathrm{~N}_{4}$ was increased from $4 \%$ to $15 \%$. This might be due to the fast recombination of the electron-hole pair in $g-\mathrm{C}_{3} \mathrm{~N}_{4}$. Furthermore, from Figure 5, $0.5 \mathrm{CNS} / \mathrm{TiO}_{2}$ gave a higher IMI degradation rate than that of $1 \mathrm{CNS} / \mathrm{TiO}_{2}$, as seen from the slope. However, the IMI removal efficiencies obtained from the $4 \mathrm{CNS} / \mathrm{TiO}_{2}$ treatment were higher during 0-120 min. Effective photodegradation of organic compounds requires a suitable amount of stable radical species in the aqueous media. Too-high concentrations of radical species may cause termination of the radical reaction pathway, while insufficient radical concentrations resulted in slow degradation rates and low removal efficiencies. We could explain the removal efficiencies by the varied concentrations of radicals over time. Hence, after $150 \mathrm{~min}$, three samples (i.e., $0.5 \mathrm{CNS} / \mathrm{TiO}_{2}$, $1 C N S / \mathrm{TiO}_{2}$, and $\mathrm{TiO}_{2}$ ) gave \% IMI removal efficiencies of $80 \%$ and above, likely due to the suitable amount of stable radical species in the aqueous media through the prolonged degradation process. 

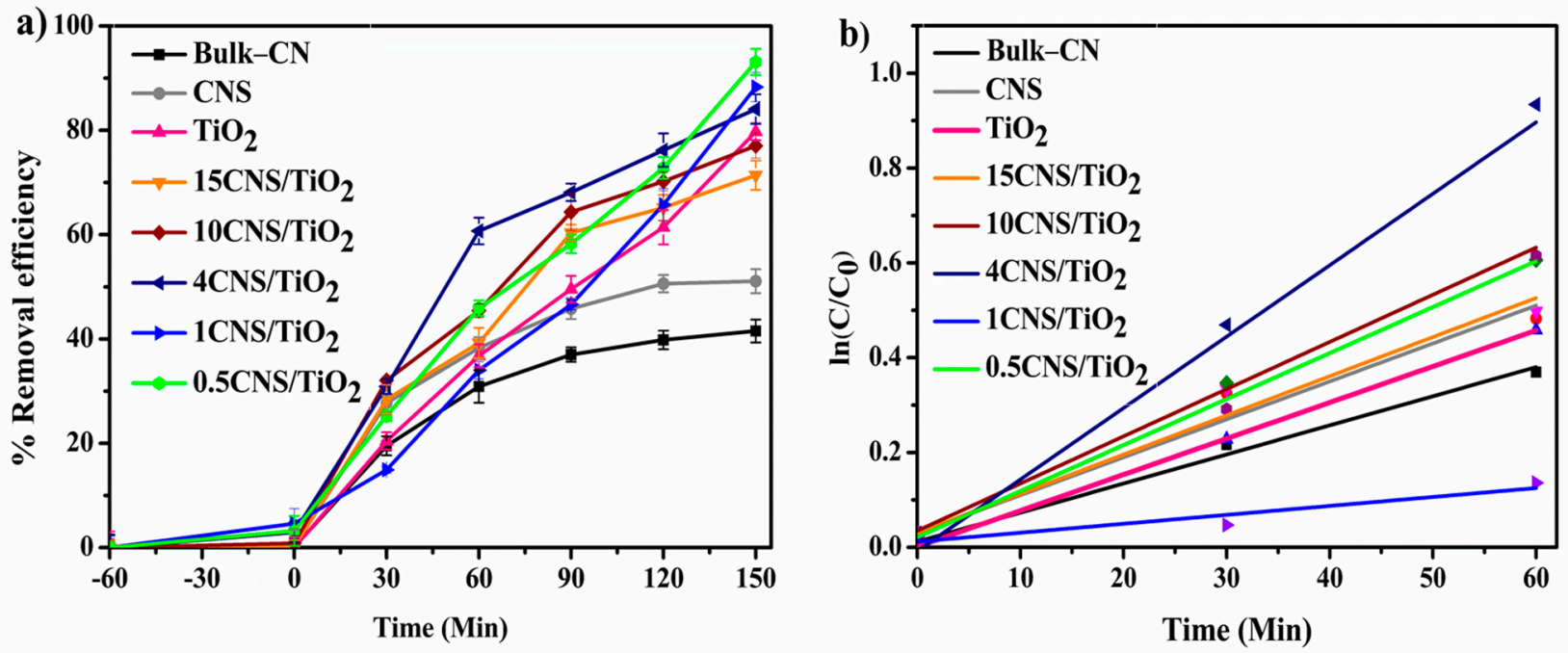

Figure 5. (a) Photocatalytic degradation of imidacloprid when treated with $\mathrm{g}-\mathrm{C}_{3} \mathrm{~N}_{4}$, $\mathrm{TiO}_{2}$, and g- $\mathrm{C}_{3} \mathrm{~N}_{4} / \mathrm{TiO}_{2}$ composites under UV-Vis light irradiation (10 ppm of pesticide and $1 \mathrm{~g} / \mathrm{L}$ of catalyst loading), and (b) the first-order kinetic fitting curve of the photocatalytic IMI degradation during 30 min irradiation time.

The initial rate constants, derived from the first-order kinetic fitting curve (Figure $5 b$ ), for the photodegradation of IMI from the highest to the lowest, are given in the order of $4 \mathrm{CN} / \mathrm{TiO}_{2}\left(1.50 \times 10^{-2} \mathrm{~min}^{-1}\right), 10 \mathrm{CNS} / \mathrm{TiO}_{2}\left(9.96 \times 10^{-3} \mathrm{~min}^{-1}\right), 0.5 \mathrm{CNS} / \mathrm{TiO}_{2}$ $\left(9.70 \times 10^{-3} \mathrm{~min}^{-1}\right), 15 \mathrm{CNS} / \mathrm{TiO}_{2}\left(8.26 \times 10^{-3}\right), \mathrm{CNS}\left(8.00 \times 10^{-3} \mathrm{~min}^{-1}\right), \mathrm{TiO}_{2}$ $\left(7.60 \times 10^{-3} \mathrm{~min}^{-1}\right)$, bulk-CN $\left(6.13 \times 10^{-3} \mathrm{~min}^{-1}\right)$, and $1 \mathrm{CNS} / \mathrm{TiO}_{2}\left(1.88 \times 10^{-3} \mathrm{~min}^{-1}\right)$ catalysts. As a result, the initial rate constants are poorly correlated with the IMP removal efficiencies after $180 \mathrm{~min}$ of irradiation time, possibly due to the stability of radical species as a function of time discussed earlier.

\subsection{Reusability and Regeneration}

The stability of the photocatalysts was evaluated over multiple cycles of IMI degradation. As shown in Figure $6 \mathrm{a}$, the IMI removal efficiency of $0.5 \mathrm{CN} / \mathrm{TiO}_{2}$ decreased significantly in the fourth cycle. The SEM image (Figure $6 \mathrm{~b}, \mathrm{c}$ ) shows that the sheet-like morphology of the photocatalyst remained. However, the surface of the catalysts could be covered either by reactants or products that hindered photocatalytic performance. A regeneration experiment was carried out. After the photocatalysis experiment, the catalyst was separated from the reaction mixture by centrifugation. The used photocatalyst was regenerated by stirring in water (dark) for $1 \mathrm{~h}$ and irradiated for $2.5 \mathrm{~h}$ before using it in the next cycle. It was found that the $0.5 \mathrm{CN} / \mathrm{TiO}_{2}$ composite still kept $\sim 91 \%$ regeneration efficiency at the end of the fourth cycle, indicating a relatively high regeneration potential of the nanocomposite.

From this work, the bulk carbon nitride is less suitable than the exfoliated material to be incorporated with $\mathrm{TiO}_{2}$ for photocatalytic applications. The IMI removal efficiencies obtained from the $4 \mathrm{CNS} / \mathrm{TiO}_{2}$ treatment are significantly higher (ca. 30\%) than those obtained from $4 \mathrm{CN} / \mathrm{TiO}_{2}$ (Figure $\mathrm{S1}$, Supplementary Data). The photocatalytic performance of several carbon nitride based composites in the degradation of imidacloprid is given in Table 1. 

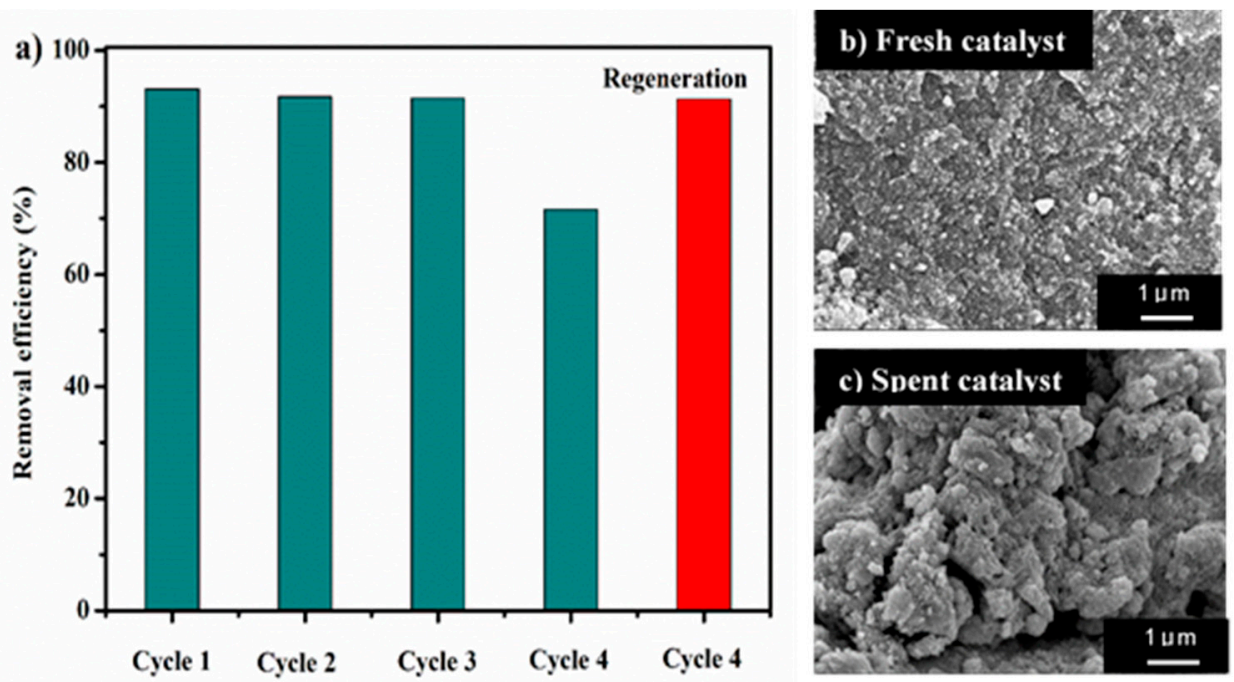

Figure 6. (a) Reusability and regeneration performance test of $0.5 \mathrm{CN} / \mathrm{TiO}_{2}$ for imidacloprid degradation, SEM images of $(\mathbf{b})$ fresh and $(\mathbf{c})$ spent $0.5 \mathrm{CN} / \mathrm{TiO}_{2}$ photocatalyst

Table 1. Comparative photocatalytic degradation of imidacloprid pesticide at varying conditions, over various carbon nitride based materials.

\begin{tabular}{|c|c|c|c|c|c|c|}
\hline Photocatalyst & Light Source & $\begin{array}{l}\text { Cat. Loading } \\
\text { (g/L) }\end{array}$ & $\begin{array}{l}\text { Initial (IMI) } \\
\text { (ppm) }\end{array}$ & $\begin{array}{c}\text { Irradiation } \\
\text { Time (h) }\end{array}$ & $\begin{array}{c}\text { Best Removal } \\
\text { Eff. (\%) }\end{array}$ & Ref. \\
\hline $\begin{array}{c}\mathrm{g}-\mathrm{C}_{3} \mathrm{~N}_{4} \text { (urea) } \\
\mathrm{g}-\mathrm{C}_{3} \mathrm{~N}_{4} \text { (melamine) }\end{array}$ & $\begin{array}{c}\lambda>400 \mathrm{~nm}(8 \\
W)\end{array}$ & $\begin{array}{l}0.5 \\
1.0\end{array}$ & 20 & 5.0 & $\begin{array}{l}90 \\
43\end{array}$ & [60] \\
\hline $\mathrm{Ag}_{2} \mathrm{O} / \mathrm{g}-\mathrm{C}_{3} \mathrm{~N}_{4}$ & $\begin{array}{l}\text { Infrared lamp } \\
\qquad(250 \mathrm{~W})\end{array}$ & 1.0 & 10 & 2.0 & 80 & [61] \\
\hline $\begin{array}{c}\mathrm{g}-\mathrm{C}_{3} \mathrm{~N}_{4} \\
\text { P doped } g-\mathrm{C}_{3} \mathrm{~N}_{4}(\mathrm{PCN}) \\
0.04 \mathrm{C}_{60} / \mathrm{PCN}\end{array}$ & $\begin{array}{l}\text { LED lamp } \\
\qquad(35 \mathrm{~W})\end{array}$ & 0.6 & 26 & 9.0 & $\begin{array}{l}60 \\
72 \\
95\end{array}$ & [62] \\
\hline $\begin{array}{c}\mathrm{g}-\mathrm{C}_{3} \mathrm{~N}_{4} \\
\text { Ag-Bi }{ }_{2} \mathrm{O}_{3} / g-\mathrm{C}_{3} \mathrm{~N}_{4}\end{array}$ & $\begin{array}{l}\text { LED lamp } \\
(35 \mathrm{~W})\end{array}$ & 0.5 & 26 & 8.0 & $\begin{array}{l}65 \\
98 \\
\end{array}$ & [63] \\
\hline $\mathrm{Bi}_{2} \mathrm{WO}_{6}: \mathrm{NH}_{2}-\mathrm{MOF}$ & Xe lamp & 0.4 & 10 & 3.0 & 84 & {$[64]$} \\
\hline $\mathrm{Ag}_{4} \mathrm{~V}_{2} \mathrm{O}_{7} / \mathrm{g}-\mathrm{C}_{3} \mathrm{~N}_{4}$ & $\begin{array}{l}\text { Xe lamp } \\
(300 \mathrm{~W})\end{array}$ & 1.0 & 10 & 4.0 & 38 & [65] \\
\hline $\begin{array}{c}\mathrm{g}-\mathrm{C}_{3} \mathrm{~N}_{4} \text { (urea) } \\
\mathrm{CNS} \\
0.5 \mathrm{CNS} / \mathrm{TiO}_{2}\end{array}$ & W lamp $(300 \mathrm{~W})$ & 1.0 & 10 & 2.5 & $\begin{array}{l}42 \\
51 \\
93\end{array}$ & $\begin{array}{l}\text { This } \\
\text { work }\end{array}$ \\
\hline
\end{tabular}

As seen in Table 1, a quite prolonged reaction time $(5 \mathrm{~h})$ was required in order to achieve high IMI removal efficiencies in the photocatalytic treatments of IMI (aq) over the g- $\mathrm{C}_{3} \mathrm{~N}_{4}$ materials, and the photocatalytic performance of $\mathrm{g}-\mathrm{C}_{3} \mathrm{~N}_{4}$ is precursor-dependent. Direct comparison of the catalytic performance of the reported photocatalysts and those developed in this work could not be entirely appropriate as each report utilized specific performance testing setups and conditions (initial concentration, catalyst loading, and reaction time). Nevertheless, a greater number of steps and expensive chemicals would be required to prepare several functional photocatalysts $\left(0.04 \mathrm{C}_{60} / \mathrm{PCN}, \mathrm{Ag}-\mathrm{Bi}_{2} \mathrm{O}_{3} / \mathrm{g}-\mathrm{C}_{3} \mathrm{~N}_{4}\right.$, $\mathrm{Bi}_{2} \mathrm{WO}_{6}: \mathrm{NH}_{2}-\mathrm{MOF}, \mathrm{Ag}_{4} \mathrm{~V}_{2} \mathrm{O}_{7} / \mathrm{g}-\mathrm{C}_{3} \mathrm{~N}_{4}$ ), compared to this work.

\subsection{Photocatalytic Mechanism}

To find out the major active species for the photocatalytic oxidation, several scavengers were added to the photocatalytic system individually to trap and remove active species 
(Figure 7). Ammonium oxalate (AO), isopropanol (IPA), and benzoquinone (BQ) act as scavengers to holes $\left(\mathrm{h}^{+}\right)$, hydroxyl radical $(\bullet \mathrm{OH})$, and superoxide radical $\left(\bullet \mathrm{O}_{2}{ }^{-}\right)$, respectively. The addition of $\mathrm{p}$-benzoquinone had a little effect on the photocatalytic degradation of IMI, implying that $\bullet \mathrm{O}_{2}{ }^{-}$has a minor role in the reaction as an oxidative species. In contrast, the photodegradation activity of the $0.5 \mathrm{CNS} / \mathrm{TiO}_{2}$ had a dramatic decrease with the addition of IPA and $\mathrm{AO}$, suggesting that both $\mathrm{OH}^{-}$and holes are the main oxidative species in this system.

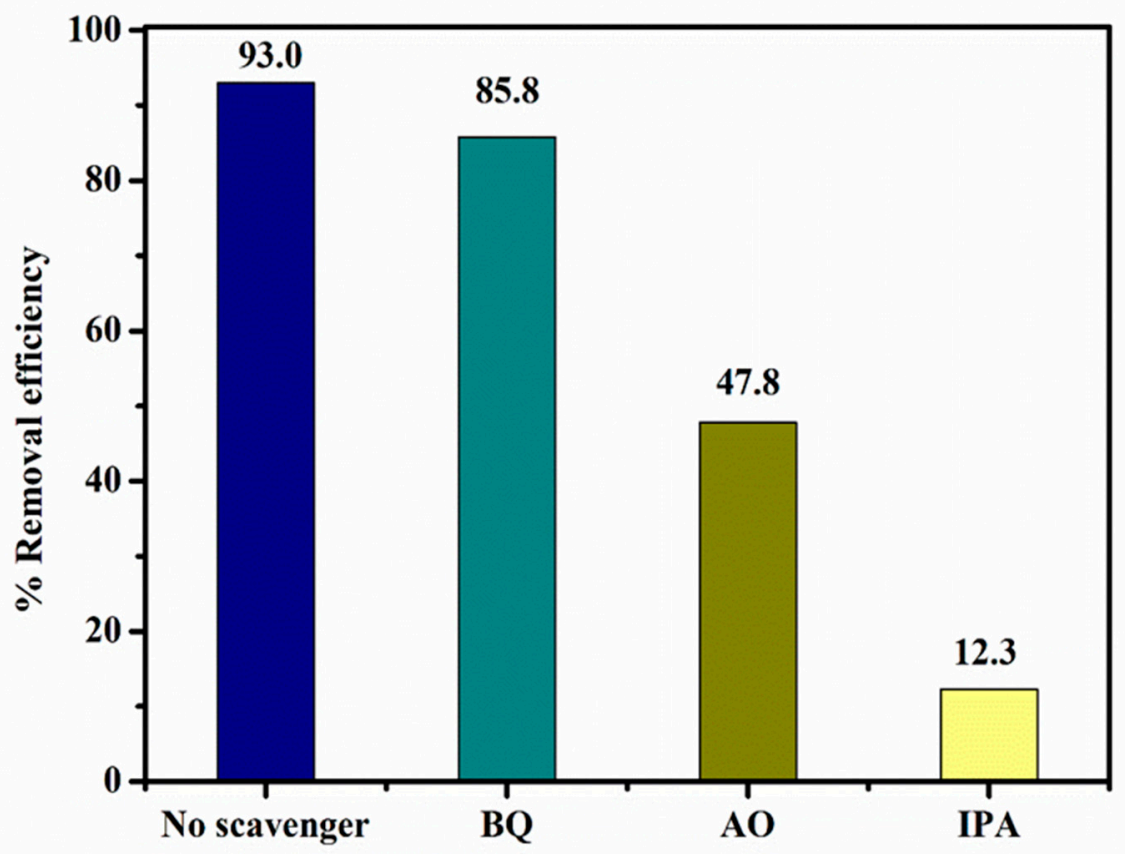

Figure 7. Effects of different scavengers on the photocatalytic degradation of IMI.

In order to describe the photocatalytic mechanism of $0.5 \mathrm{CNS} / \mathrm{TiO}_{2}$ for the degradation of IMI, the CB and VB edge potentials of $g-\mathrm{C}_{3} \mathrm{~N}_{4}$ and $\mathrm{TiO}_{2}$ were calculated from Equations (2) and (3) [66].

$$
\begin{gathered}
E_{C B}=X-E_{C}-1 / 2 E_{g} \\
E_{V B}=E_{C B}+E_{g}
\end{gathered}
$$

where $\mathrm{X}$ is the absolute electronegativity of the atom semiconductor, and the $\mathrm{X}$ values of $\mathrm{TiO}_{2}$ and $\mathrm{g}-\mathrm{C}_{3} \mathrm{~N}_{4}$ are $5.8 \mathrm{eV}$ and $4.73 \mathrm{eV}$, respectively [66]. $\mathrm{E}_{\mathrm{C}}$ is the energy of free electrons of the hydrogen scale $(4.5 \mathrm{Ev}) . \mathrm{E}_{\mathrm{g}}$ is the band gap of the semiconductor which is 2.93 and $3.20 \mathrm{eV}$ for $\mathrm{g}-\mathrm{C}_{3} \mathrm{~N}_{4}$ and $\mathrm{TiO}_{2}$, respectively. Therefore, the reductive potentials of the conduction band $(\mathrm{CB})$ are -0.30 and $-1.23 \mathrm{~V}$ for $\mathrm{TiO}_{2}$ and $\mathrm{g}-\mathrm{C}_{3} \mathrm{~N}_{4}$, and the oxidizing potentials of the valence band $(\mathrm{VB})$ of $\mathrm{TiO}_{2}$ and $\mathrm{g}-\mathrm{C}_{3} \mathrm{~N}_{4}$ are +2.90 and $+1.70 \mathrm{~V}$, respectively.

Based on the above results, the possible Z-scheme photocatalytic mechanism of $\mathrm{g}-\mathrm{C}_{3} \mathrm{~N}_{4} / \mathrm{TiO}_{2}$ was proposed as shown in Figure 8. Under UV-Vis irradiation, $\mathrm{TiO}_{2}$ absorbed photon energy, and then electrons were excited from the VB to the $\mathrm{CB}$. The photogenerated holes tended to stay in the $\mathrm{VB}$ of $\mathrm{TiO}_{2}$, whereas photogenerated electrons on the $\mathrm{CB}$ of $\mathrm{TiO}_{2}$ can be directly transferred into the $\mathrm{VB}$ of $\mathrm{g}-\mathrm{C}_{3} \mathrm{~N}_{4}$ due to their proximity to each other. Then, the electrons in the $\mathrm{VB}$ of $\mathrm{g}-\mathrm{C}_{3} \mathrm{~N}_{4}$ are further excited into the $\mathrm{CB}$. This resulted in an efficient charge separation of the photo-induced electron-hole pair and an enhancement in their oxidation-reduction ability. Specifically, the presence of $\mathrm{Ti}^{3+}$ and oxygen vacancy could be an important reason for the hindrance of the electron-hole recombination. It was found that the photogenerated holes $\left(\mathrm{h}^{+}\right)$in the $\mathrm{VB}$ of $\mathrm{TiO}_{2}\left(\mathrm{E}_{\mathrm{VB}}=2.90 \mathrm{~V}\right.$ vs. NHE) have the ability to oxidize $\mathrm{H}_{2} \mathrm{O}$ or hydroxyl ions $\left(\mathrm{OH}^{-}\right)$to hydroxyl radicals $(\bullet \mathrm{OH})$, while the photogenerated $\mathrm{h}^{+}$in the VB of $\mathrm{g}-\mathrm{C}_{3} \mathrm{~N}_{4}\left(\mathrm{E}_{\mathrm{VB}}=1.70 \mathrm{~V}\right.$ vs. $\left.\mathrm{NHE}\right)$ is not sufficient for the oxidation of $\mathrm{H}_{2} \mathrm{O}$ to hydroxyl radicals. In addition, the photogenerated electron in the $C B$ of $g-C_{3} N_{4}$ was 
trapped on the surface to form reactive superoxide radical ions $\left(\bullet \mathrm{O}_{2}{ }^{-}\right)$. The photocatalytic mechanism was consistent with the scavenger experiments in which the hydroxyl radical and holes were the principal reactive species for the IMI degradation, whereas the superoxide radical had a minor role. The Z-scheme photocatalyst was suggested since the photogenerated $\mathrm{h}+$ on the $\mathrm{TiO}_{2} / \mathrm{g}-\mathrm{C}_{3} \mathrm{~N}_{4}$ composite has a sufficient oxidation potential for producing $\bullet \mathrm{OH}$ radicals [67]. Evaluated by using Equations (2) and (3), the reduction potential of $\mathrm{g}-\mathrm{C}_{3} \mathrm{~N}_{4}(+1.70 \mathrm{~V})$ is less positive to oxidize $\mathrm{H}_{2} \mathrm{O}$ to $\bullet \mathrm{OH}(+1.99 \mathrm{~V})$. Thus, the holes in the $\mathrm{VB}$ of g- $\mathrm{C}_{3} \mathrm{~N}_{4}$ cannot adsorb water molecules near the surface of $\mathrm{g}-\mathrm{C}_{3} \mathrm{~N}_{4}$ to generate hydroxyl radicals $(\bullet \mathrm{OH})$. Note that $\bullet \mathrm{OH}$ radicals can be produced on semiconductors with an oxidation potential of $2.4 \mathrm{~V}$ (and above) versus NHE. The scavenging testing indicated that $\bullet \mathrm{OH}$ radicals are the key radicals promoting effective IMI degradation. The Z-scheme g- $\mathrm{C}_{3} \mathrm{~N}_{4} / \mathrm{TiO}_{2}$ composites showed better photocatalytic performance than $\mathrm{TiO}_{2}$ or g- $\mathrm{C}_{3} \mathrm{~N}_{4}$ alone. However, with the content of $\mathrm{g}-\mathrm{C}_{3} \mathrm{~N}_{4}$ in $\mathrm{g}-\mathrm{C}_{3} \mathrm{~N}_{4} / \mathrm{TiO}_{2}$ being in excess, numerous photo-induced electrons and holes would recombine easily. Therefore, the $0.5 \mathrm{CNS} / \mathrm{TiO}_{2}$ sample displayed the best photocatalytic performance among these different $g-\mathrm{C}_{3} \mathrm{~N}_{4} / \mathrm{TiO}_{2}$ photocatalysts.

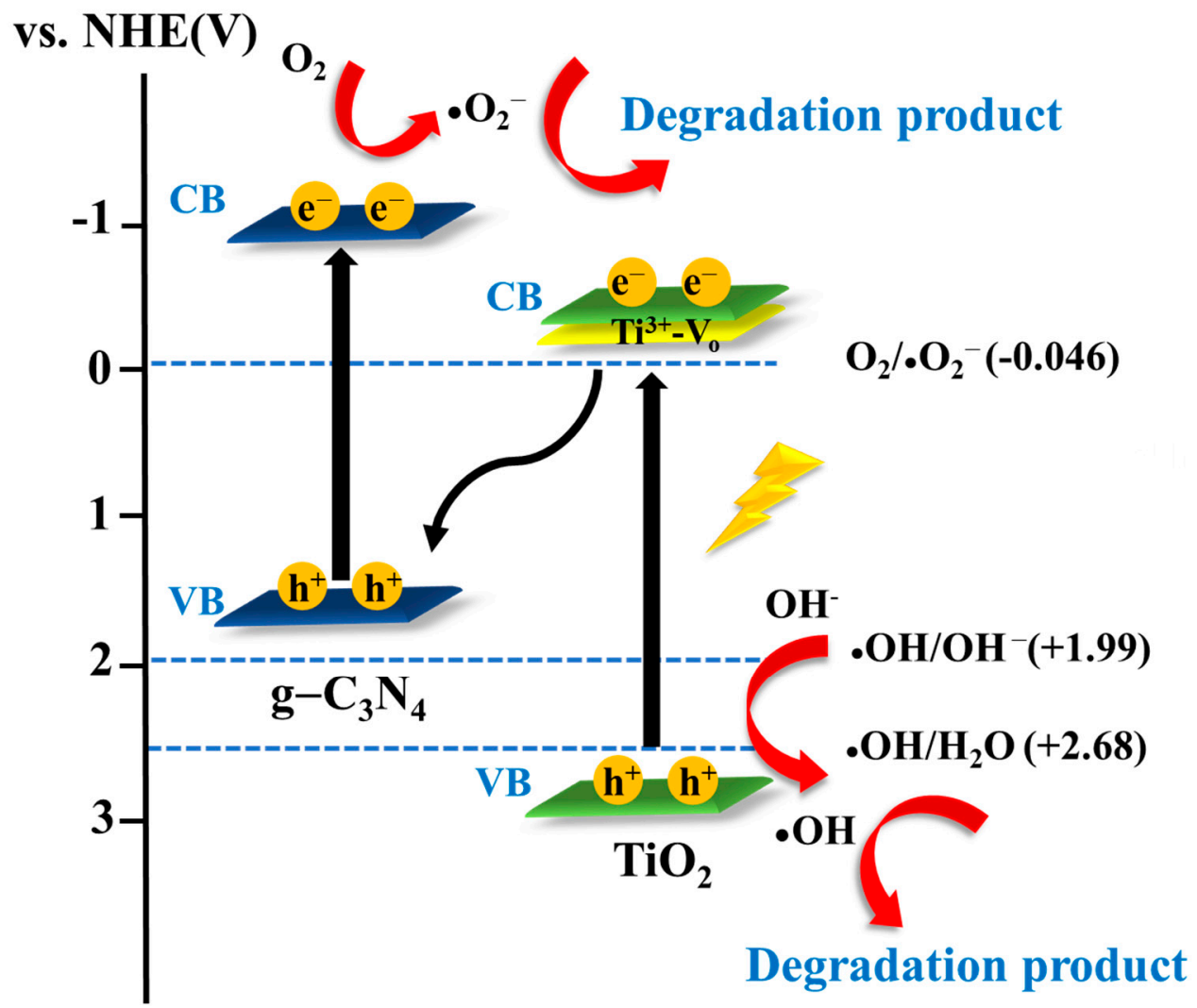

Figure 8. Photocatalytic mechanism of $0.5 \mathrm{CNS} / \mathrm{TiO}_{2}$ for degradation of imidacloprid.

\section{Materials and Methods}

\subsection{Chemicals}

Urea $\left(\mathrm{CH}_{4} \mathrm{~N}_{2} \mathrm{O}\right)$ was obtained from Kemaus, Australia. Ammonium oxalate $\left(\mathrm{NH}_{4}\right)_{2} \mathrm{C}_{2} \mathrm{O}_{4}$, nitric acid $\left(\mathrm{HNO}_{3}\right)$, and methanol $\left(\mathrm{CH}_{3} \mathrm{OH}\right)$ were purchased from Merck, Darmstadt, Germany. Benzoquinone, isopropyl alcohol, titanium (IV) oxysulfate $\left(\mathrm{TiOSO}_{4}\right)$ and imidacloprid were obtained from Sigma-Aldrich, USA. All reagents were of analytical grade and were used without further purification. Deionized water was used in preparing all aqueous solutions. 


\subsection{Characterization}

The sample was determined using powder X-ray diffraction (Bruker AXS, D8 advance, Germany) with $\mathrm{CuK} \alpha$ radiation $(\lambda=1.54 \AA)$ and was collected in $2 \theta$ range from $10^{\circ}$ to $90^{\circ}$. The X-ray photoelectron spectroscopy (XPS) was carried out to determine the surface electronic state of the samples with a monochromatized Al K $\alpha$ radiation source (AXIS Ultra DLD, Japan). The Raman spectra were recorded using Raman microscope at laser wavelength of $785 \mathrm{~nm}$ (Horiba, XploRA Plus, France). The electron paramagnetic resonance (EPR) signals of free radicals were recorded at ambient temperature (Bruker; Elexsys 500, Germany). The morphologies and elemental composites of the samples were examined by a scanning electron microscope (JEOL, JSM-IT500, Japan) and Field emission scanning electron microscope (FE-SEM, JEOL, JSM-7610FPlus, Japan). Photoluminescence (PL) spectrum was performed with excitation at $320 \mathrm{~nm}$ (Horiba, FluoroMax, France). The band gap energy of the prepared samples was carried out by UV-Vis NIR spectrophotometer (Shimadzu, UV3600 plus, Tokyo, Japan). The degradation of IMI was monitored by measuring the absorbance at $268 \mathrm{~nm}$ with a UV-Vis spectrophotometer (Perkin Elmer, Lambda 800, MA, USA).

\subsection{Synthesis of $g-C_{3} N_{4}$}

Bulk-g- $\mathrm{C}_{3} \mathrm{~N}_{4}$ was prepared by direct pyrolysis of urea according to a reported procedure with modification [68]. In detail, $125 \mathrm{~g}$ of urea was put into an alumina crucible with a cover and heated with a heating rate of $10{ }^{\circ} \mathrm{C} / \mathrm{min}$ to $600^{\circ} \mathrm{C}$ for $4 \mathrm{~h}$. After being cooled to room temperature, the pale yellow of bulk-g- $\mathrm{C}_{3} \mathrm{~N}_{4}(\mathrm{CN})$ was obtained. The bulk-CN was exfoliated into a nanosheet structure by thermal exfoliation in the presence of acid, and $2.5 \mathrm{~g}$ of bulk-CN was stirred in $65 \%$ of $\mathrm{HNO}_{3}$ solution $(100 \mathrm{~mL})$ for $12 \mathrm{~h}$. The dispersion was filtrated and washed several times with D.I. water, followed by annealing at $500{ }^{\circ} \mathrm{C}$ for $4 \mathrm{~h}$ to obtain $\mathrm{g}-\mathrm{C}_{3} \mathrm{~N}_{4}$ nanosheet $(\mathrm{CNS})$.

\subsection{Synthesis of $g-\mathrm{C}_{3} \mathrm{~N}_{4} / \mathrm{TiO}_{2}$ Composites}

g- $\mathrm{C}_{3} \mathrm{~N}_{4} / \mathrm{TiO}_{2}$ composites were prepared by a hydrothermal method. Firstly, $\mathrm{TiOSO}_{4}$ suspensions were obtained by sonication for $35 \mathrm{~min}$ in D.I. water. After dispersing, CNS was added into the solution and was sonicated continuously for $30 \mathrm{~min}$. The solution was transferred to a Teflon-lined autoclave which was then further heated at $180{ }^{\circ} \mathrm{C}$ for $4 \mathrm{~h}$. The obtained solution was centrifuged, washed with D.I. water, and dried at $65^{\circ} \mathrm{C}$ for $24 \mathrm{~h}$. According to the above method, different weight ratios of $\mathrm{g}-\mathrm{C}_{3} \mathrm{~N}_{4}$ to $\mathrm{TiO}_{2}$ at $0.5 \%, 1 \%, 4 \%, 10 \%$, and $15 \%$ were synthesized and labeled as $0.5 \mathrm{CNS} / \mathrm{TiO}_{2}, 1 \mathrm{CNS} / \mathrm{TiO}_{2}$, $4 \mathrm{CNS} / \mathrm{TiO}_{2}, 10 \mathrm{CNS} / \mathrm{TiO}_{2}$, and $15 \mathrm{CNS} / \mathrm{TiO}_{2}$, respectively. $\mathrm{TiO}_{2}$ was also prepared by the same procedure without adding g- $\mathrm{C}_{3} \mathrm{~N}_{4}$.

\subsection{Photocatalytic Activity}

The photocatalytic behavior of the catalyst was evaluated by the photodegradation of imidacloprid in an aqueous solution with an initial concentration of $10 \mathrm{mg} / \mathrm{L}$ under 300 watts of W lamp. First, $10 \mathrm{mg}$ of photocatalyst was added to $10 \mathrm{~mL}$ of IMI solution. The suspension was stirred using a magnetic stirrer in the dark at room temperature for $1 \mathrm{~h}$ before irradiation. The solution was collected every $30 \mathrm{~min}$ to $150 \mathrm{~min}$ using a syringe with a microspore filter $(0.45 \mu \mathrm{m})$. The concentration of IMI was analyzed by UV-Vis spectrophotometry at $268 \mathrm{~nm}$, and the removal efficiency was calculated via Equation (4) [69].

Where $\mathrm{C}_{0}$ is the initial concentration of IMI, and $\mathrm{C}_{\mathrm{t}}$ is the concentration of IMI after $\mathrm{t}$ minutes.

To study the reaction kinetic, the obtained data were fitted by a first-order kinetic model which is shown in Equation (2).

$$
\ln \left(\mathrm{C}_{0} / \mathrm{C}\right)=\mathrm{kt}
$$


where $\mathrm{k}$ is the pseudo-first-order rate constant, $\mathrm{C}_{0}$ is the initial IMI concentration, and $\mathrm{C}$ is imidacloprid equilibrium concentration in aqueous solution at time $t$.

\subsection{Scavenger Activity}

Active species capture experiments were used to study the photocatalysis mechanism. First, isopropyl alcohol (IPA; $0.5 \mathrm{mM}$ ) was used as the hydroxyl scavenger $\left(\bullet \mathrm{OH}^{*}\right)$, benzoquinone $(\mathrm{BQ} ; 0.5 \mathrm{mM})$ was employed as the superoxide scavenger $\left(\bullet \mathrm{O}_{2}{ }^{-}\right)$, and ammonium oxalate $(\mathrm{AO} ; 0.5 \mathrm{mM})$ was used as the hole scavenger $\left(\mathrm{h}^{+}\right)$[70]. Different scavengers were used in the trapping experiments to check the inhibitory effect of scavengers during the photocatalytic reaction under analogous irradiation experimental conditions.

\section{Conclusions}

In this work, $g-C_{3} N_{4}$ nanosheets were exfoliated from bulk-g- $C_{3} N_{4}$ by thermal exfoliation in the presence of $\mathrm{HNO}_{3}$. The exfoliated $\mathrm{g}-\mathrm{C}_{3} \mathrm{~N}_{4}$ resulted in nanosheets with a large specific surface area and $\mathrm{N}$ vacancy defects, which can be prepared and further used in the fabrication of $\mathrm{TiO}_{2}$ base composites having superior photocatalytic activity, under UV-Vis light irradiation, to bulk the $\mathrm{g}-\mathrm{C}_{3} \mathrm{~N}_{4}$ and $\mathrm{g}-\mathrm{C}_{3} \mathrm{~N}_{4} / \mathrm{TiO}_{2}$ composites. Results show that the $\mathrm{g}-\mathrm{C}_{3} \mathrm{~N}_{4} / \mathrm{TiO}_{2}$ photocatalyst exhibited higher removal efficiency for IMI than g- $\mathrm{C}_{3} \mathrm{~N}_{4}$ and $\mathrm{TiO}_{2}$, indicating that a synergistic effect exists between $\mathrm{Ti}^{3+}-\mathrm{TiO}_{2}$ and $\mathrm{g}-\mathrm{C}_{3} \mathrm{~N}_{4}$. With the increase of $g-\mathrm{C}_{3} \mathrm{~N}_{4}$ loading, the photocatalytic activity of $\mathrm{g}-\mathrm{C}_{3} \mathrm{~N}_{4} / \mathrm{TiO}$ composites may also decrease the photocatalytic activity of $\mathrm{g}-\mathrm{C}_{3} \mathrm{~N}_{4}$. The sample of $0.5 \mathrm{CNS} / \mathrm{TiO}_{2}$ showed the highest photocatalytic activity with 93\% removal efficiency within $150 \mathrm{~min}$. The enhanced photocatalytic performance of the $\mathrm{g}-\mathrm{C}_{3} \mathrm{~N}_{4} / \mathrm{TiO}_{2}$ composites could be due to the generation of reactive oxidation species induced by photogenerated electrons and the effective suppression of the recombination of the charge carriers. In addition, the g- $\mathrm{C}_{3} \mathrm{~N}_{4} / \mathrm{TiO}_{2}$ photocatalyst showed good stability for multiple recycling. Thus, the $\mathrm{g}-\mathrm{C}_{3} \mathrm{~N}_{4} / \mathrm{TiO}_{2}$ could be effectively used as material for the photodegradation of imidacloprid pesticide in wastewater. Comprehensive photoelectrochemical analysis of the $\mathrm{g}-\mathrm{C}_{3} \mathrm{~N}_{4} / \mathrm{TiO}_{2}$ materials should be further studied to obtain the photogenerated charge recombination rates in detail.

Supplementary Materials: The following supporting information can be downloaded at: https: / / www.mdpi.com/article/10.3390/catal12020120/s1, Figure S1: Powder XRD patterns of $1 \mathrm{CNS}^{\mathrm{T}} \mathrm{TiO}_{2}$, $4 \mathrm{CNS} / \mathrm{TiO}_{2}, 10 \mathrm{CNS} / \mathrm{TiO}_{2}$, and $15 \mathrm{CNS} / \mathrm{TiO}_{2}$, Figure S2: Photolysis of imidacloprid.

Author Contributions: Conceptualization, methodology, formal analysis, investigation, visualization, T.K. and S.M.S.; writing - original draft preparation, T.K. and J.T.; writing - review and editing, S.M.S.; supervision, T.A. and S.M.S.; writing-review and editing, S.M.S.; resources, P.K. and S.M.S.; funding acquisition, P.K. and S.M.S. All authors have read and agreed to the published version of the manuscript.

Funding: National Research Council of Thailand (Grant No. IRN62W0005).

Data Availability Statement: The data presented in this study are openly available in Mendeley repository at doi:10.17632/3v2mgmgzpz.1.

Acknowledgments: This work was partially supported by the National Research Council Thailand (Grant No. IRN62W0005). We thank Mahidol University Frontier Research Facility (MU-FRF) for instrument support and the MU-FRF scientists, Nawapol Udpuay and Suwilai Chaveanghong, for their kind assistance in Raman and FE-SEM analyses.

Conflicts of Interest: The authors declare no conflict of interest. 


\section{References}

1. Wumuerhan, P.; Yuntao, J.; Deying, M. Effects of exposure to imidacloprid direct and poisoned cotton aphids Aphis gossypii on ladybird Hippodamia variegata feeding behavior. J. Pestic. Sci. 2020, 45, 24-28. [CrossRef]

2. Stanneck, D.; Ebbinghaus-Kintscher, U.; Schoenhense, E.; Kruedewagen, E.M.; Turberg, A.; Leisewitz, A.; Jiritschka, W.; Krieger, K.J. The synergistic action of imidacloprid and flumethrin and their release kinetics from collars applied for ectoparasite control in dogs and cats. Parasites Vectors 2012, 5, 73. [CrossRef]

3. Borsuah, J.F.; Messer, T.L.; Snow, D.D.; Comfort, S.D.; Mittelstet, A.R. Literature review: Global neonicotinoid insecticide occurrence in aquatic environments. Water 2020, 12, 3388. [CrossRef]

4. $\quad$ Berheim, E.H.; Jenk, J.A.; Lundgren, J.G.; Michel, E.S.; Grove, D.; Jensen, W.F. Effects of neonicotinoid insecticides on physiology and reproductive characteristics of captive female and fawn white-tailed deer. Sci. Rep. 2019, 9, 4534. [CrossRef]

5. Yang, E.C.; Chuang, Y.C.; Chen, Y.L.; Chang, L.H. Abnormal foraging behavior induced by sublethal dosage of imidacloprid in the honey bee (Hymenoptera: Apidae). J. Econ. Entomol. 2008, 101, 1743-1748. [CrossRef]

6. Nyman, A.-M.; Hintermeister, A.; Schirmer, K.; Ashauer, R. The insecticide imidacloprid causes mortality of the freshwater amphipod gammarus pulex by interfering with feeding behavior. PLoS ONE 2013, 8, e62472. [CrossRef]

7. Sriapha, C.; Trakulsrichai, S.; Tongpool, A.; Pradoo, A.; Rittilert, P.; Wananukul, W. Acute imidacloprid poisoning in Thailand. Ther. Clin. Risk Manag. 2020, 16, 1081-1088. [CrossRef]

8. Mundhe, S.A.; Birajdar, S.V.; Chavan, S.S.; Pawar, N.R. Imidacloprid poisoning: An emerging cause of potentially fatal poisoning. Indian J. Crit Care Med. 2017, 21, 786-788. [CrossRef]

9. Crall, J.D.; Switzer, C.M.; Oppenheime, R.L.; Versypt, A.N.F.; Dey, B.; Brown, A.; Eyster, M.; Guérin, C.; Pierce, N.E.; Combes, S.A.; et al. Neonicotinoid exposure disrupts bumblebee nest behavior, social networks, and thermoregulation. Science 2018, 362, 683-686. [CrossRef]

10. Patil, A.L.; Patil, P.N.; Gogate, P.R. Degradation of imidacloprid containing wastewaters using ultrasound-based treatment strategies. Ultrason. Sonochem. 2014, 21, 1778-1786. [CrossRef]

11. Zhang, Y.; Lu, H.; Wang, B.; Zhang, Z.; Lin, X.; Chen, Z.; Li, B. Removal of imidacloprid and acetamiprid from tea infusions by microfiltration membrane. Int. J. Food Sci. 2015, 50, 1397-1404.

12. Sabourmoghaddam, N.; Zakaria, M.P.; Omar, D. Evidence for the microbial degradation of imidacloprid in soils of Cameron Highlands. J. Saudi Soc. Agric. Sci. 2015, 14, 182-188. [CrossRef]

13. Urbain, K.Y.; Fodjo, E.K.; Ardjouma, D.; Serge, B.Y.; Aimé, E.S.; Marc, G.B.I.; Albert, T. Removal of imidacloprid using activated carbon produced from ricinodendron heudelotii shells. Bull. Chem. Soc. Ethiop. 2017, 31, 397-409. [CrossRef]

14. Mohammad, S.G.; El-Sayed, M.M.H. Removal of imidacloprid pesticide using nanoporous activated carbons produced via pyrolysis of peach stone agricultural wastes. Chem. Eng. Commun. 2020, 208, 1069-1080. [CrossRef]

15. Soltani-nezhad, F.; Saljooqi, A.; Shamspur, T.; Mostafavi, A. Photocatalytic degradation of imidacloprid using $\mathrm{GO}^{-} \mathrm{Fe}_{3} \mathrm{O}_{4} / \mathrm{TiO}_{2}-$ $\mathrm{NiO}$ under visible radiation: Optimization by response level method. Polyhedron 2019, 165, 188-196. [CrossRef]

16. Lacson, C.F.Z.; de Luna, M.D.G.; Dong, C.; Garcia-Segura, S.; Lu, M.-C. Fluidized-bed fenton treatment of imidacloprid: Optimization and degradation pathway. Sustain. Environ. Res. 2018, 28, 309-314. [CrossRef]

17. Lee, Y.-J.; Ka, J.-K.; Park, S.-J.; Lee, C.-G.; Moon, J.-K.; Alvarez, P.J.J. Photocatalytic degradation of neonicotinoid insecticides using sulfate-doped $\mathrm{Ag}_{3} \mathrm{PO}_{4}$ with enhanced visible light activity. Chem. Eng. Sci. 2020, 402, 126183. [CrossRef]

18. Kumar, A.; Pandey, G. A review on the factors affecting the photocatalytic degradation of hazardous materials. Mater. Sci. Eng. Int. 2017, 1, 106-114. [CrossRef]

19. Wen, J.; Xie, J.; Chen, X.; Li, X. A review on g- $\mathrm{C}_{3} \mathrm{~N}_{4}$-based photocatalysts. Appl. Surf. Sci. 2017, 391, 72-123. [CrossRef]

20. Liu, R.; Chen, Z.; Yao, Y.; Li, Y.; Cheema, W.A.; Wang, D.; Zhu, S. Recent advancements in g- $\mathrm{C}_{3} \mathrm{~N}_{4}$-based photocatalysts for photocatalytic $\mathrm{CO}_{2}$ reduction: A mini review. RSC Adv. 2020, 10, 29408. [CrossRef]

21. Zou, L.R.; Huang, G.-F.; Li, D.-F.; Liu, J.-H.; Pan, A.-L.; Huang, W.-Q. A facile and rapid route for synthesis of g-C $\mathrm{C}_{3} \mathrm{~N}_{4}$ nanosheets with high adsorption capacity and photocatalytic activity. RSC Adv. 2016, 6, 86688-86694. [CrossRef]

22. Yang, Y.; Chen, J.; Mao, Z.; An, N.; Wang, D.; Fahkman, B.D. Ultrathin g- $\mathrm{C}_{3} \mathrm{~N}_{4}$ nanosheets with an extended visible-lightresponsive range for significant enhancement of photocatalysis. RSC Adv. 2017, 7, 2333. [CrossRef]

23. Wang, P.; Yang, M.; Tang, S.; Chen, F.; Li, Y. Preparation of cellular $\mathrm{C}_{3} \mathrm{~N}_{4} / \mathrm{CoSe}_{2} / \mathrm{GA}$ composite photocatalyst and its $\mathrm{CO} 2$ reduction activity. Chem. J. Chin. Univ. 2021, 42,6.

24. Jiang, L.; Yuan, X.; Pan, Y.; Liang, J.; Zeng, G.; Wu, Z.; Wang, H. Doping of graphitic carbon nitride for photocatalysis: A review. Appl. Catal. B 2017, 217, 388-406. [CrossRef]

25. Zhang, H.; Liu, F.; Wu, H.; CaO, X.; Sun, J.; Lei, W. In situ synthesis of g- $\mathrm{C}_{3} \mathrm{~N}_{4} / \mathrm{TiO}_{2}$ heterostructures with enhanced photocatalytic hydrogen evolution under visible light. RSC Adv. 2017, 7, 40327. [CrossRef]

26. Kanwal, M.; Tariq, S.R.; Chotana, G.A. Photocatalytic degradation of imidacloprid by Ag-ZnO composite. Environ. Sci. Pollut. Res. 2018, 25, 27307-27320. [CrossRef]

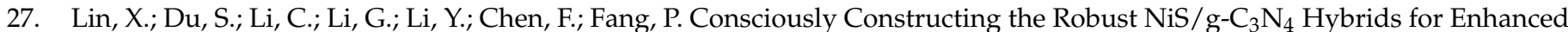
Photocatalytic Hydrogen Evolution. Catal. Lett. 2020, 150, 1898-1908. [CrossRef]

28. Chen, P.; Liu, F.; Ding, H.; Chen, S.; Chen, L.; Li, Y.-J.; Au, C.-T.; Yin, S.-F. Porous double-shell CdS@C ${ }_{3} \mathrm{~N}_{4}$ octahedron derived by in situ supramolecular self-assembly for enhanced photocatalytic activity. Appl. Catal. B Environ. 2019, 252, 33-40. [CrossRef] 
29. Schneider, J.; Matsuoka, M.; Takeuchi, M.; Zhang, J.; Horiuchi, Y.; Anpo, M.; Bahnemann, D.W. Understanding TiO 2 photocatalysis: Mechanisms and materials. Chem. Rev. 2014, 114, 9919-9986. [CrossRef]

30. Ma, Y.; Liu, E.; Hu, X.; Tang, C.; Wan, J.; Li, J.; Fan, J. A simple process to prepare few-layer g- $\mathrm{C}_{3} \mathrm{~N}_{4}$ nanosheets with enhanced photocatalytic activities. Appl. Surf. Sci. 2015, 358, 246-251. [CrossRef]

31. Niu, P.; Zhang, L.; Liu, G.; Cheng, H.-M. Graphene-like carbon nitride nanosheets for improved photocatalytic activities. Adv. Funct. Mater. 2012, 22, 4763-4770. [CrossRef]

32. Li, Y.; Yang, M.; Xing, Y.; Liu, X.; Yang, Y.; Wang, X.; Song, S. Preparation of carbon-rich g- $\mathrm{C}_{3} \mathrm{~N}_{4}$ nanosheets with enhanced visible light utilization for efficient photocatalytic hydrogen production. Small 2017, 13, 1701552. [CrossRef]

33. Robotti, M.; Dosta, S.; Cana, I.G.; Concustell, A.; Cinca, N.; Guilemany, J.M. Attrition and cryogenic milling powder production for low pressure cold gas spray and composite coatings characterization. Adv. Powder Technol. 2016, 27, 1257-1264. [CrossRef]

34. Wang, M.; Ma, F.; Wang, Z.; Hu, D.; Xu, X.; HaO, X. Graphitic carbon nitride, a saturable absorber material for the visible waveband. Photonics Res. 2018, 6, 307-313. [CrossRef]

35. El-Deen, S.S.; Hashem, A.M.; Abdel Ghany, A.E.; Indris, S.; Ehrenberg, H.; Mauger, A.; Julien, C.M. Anatase TiO 2 nanoparticles for lithium-ion batteries. Ionics 2018, 24, 2925-2934. [CrossRef]

36. Zhang, J.-R.; Ma, Y.; Wang, S.-Y.; Ding, J.; Gao, B.; Kan, E.; Hua, W. Accurate K-edge X-ray photoelectron and absorption spectra of $\mathrm{g}-\mathrm{C}_{3} \mathrm{~N}_{4}$ nanosheets by first-principles simulations and reinterpretations. Phys. Chem. Chem. Phys. 2019, 21, 22819. [CrossRef]

37. Che, W.; Cheng, W.; Yao, T.; Tang, F.; Liu, W.; Su, H.; Huang, Y.; Liu, O.; Hu, F.; Pan, Z.; et al. Fast photoelectron transfer in (C ring) $-\mathrm{C}_{3} \mathrm{~N}_{4}$ plane heterostructural nanosheets for overall water splitting. J. Am. Chem. Soc. 2017, 139, 3021-3026. [CrossRef] [PubMed]

38. Bi, G.; Wen, J.; Li, X.; Liu, W.; Xie, J.; Fang, Y.; Zhang, W. Efficient visible-light photocatalytic $\mathrm{H}_{2}$ evolution over metal-free g- $\mathrm{C}_{3} \mathrm{~N}_{4}$ co-modified with robust acetylene black and $\mathrm{Ni}(\mathrm{OH})_{2}$ as dual co-catalysts. $R S C$ Adv. 2016, 6, 31497. [CrossRef]

39. Du, X.; Bai, X.; Xu, L.; Yang, L.; Jin, P. Visible-light activation of persulfate by $\mathrm{TiO}_{2} / \mathrm{g}-\mathrm{C}_{3} \mathrm{~N}_{4}$ photocatalyst toward efficient degradation of micropollutants. Chem. Eng. Sci. 2020, 384, 123245. [CrossRef]

40. Cao, J.; Pan, C.; Ding, Y.; Li, W.; Lv, K.; Tang, H. Constructing nitrogen vacancy introduced g- $\mathrm{C}_{3} \mathrm{~N}_{4} \mathrm{p}-\mathrm{n}$ homojunction for enhanced photocatalytic activity. J. Environ. Chem. Eng. 2019, 7, 102984. [CrossRef]

41. Wang, J.; Gao, B.; Dou, M.; Huang, X.; Ma, Z. A porous g- $\mathrm{C}_{3} \mathrm{~N}_{4}$ nanosheets containing nitrogen defects for enhanced photocatalytic removal meropenem: Mechanism, degradation pathway and DFT calculation. Environ. Res. 2020, 184, 109339. [CrossRef]

42. Xi, J.; Zhang, Y.; Chen, X.; Hu, Y. A simple sol-gel hydrothermal method for the synthesis of defective $\mathrm{TiO}_{2}$ nanocrystals with excellent visible-light photocatalytic activity. Res. Chem. Intermed. 2020, 46, 2205-2214. [CrossRef]

43. Bharti, B.; Kumar, S.; Lee, H.-N.; Kumar, R. Formation of oxygen vacancies and $\mathrm{Ti}^{3+}$ state in $\mathrm{TiO}_{2}$ thin film and enhanced optical properties by air plasma treatment. Sci. Rep. 2016, 6, 32355. [CrossRef] [PubMed]

44. HaO, J.; Hu, Y.; Jiang, H.; Li, C. In situ surface hydrogenation synthesis of Ti3+self-doped TiO2 with enhanced visible light photoactivity. Nanoscale 2014, 6, 9078. [CrossRef] [PubMed]

45. Cheng, D.; Li, Y.; Yang, L.; Luo, S.; Yang, L.; Luo, X.; Luo, Y.; Li, T.; Gao, J.; Dionysiou, D.D. One step reductive synthesis of Ti ${ }^{3+}$ self-doped elongated anatase $\mathrm{TiO}_{2}$ nanowires combined with reduced graphene oxide for adsorbing and degrading waste engine oil. J. Hazard. Mater. 2019, 378, 120752. [CrossRef]

46. Swaminathan, J.; Ravichandran, S. Insights into the defect-centered electrocatalytic behavior of reduced titania (TiO 1.23$)$. J. Phys. Chem. C 2018, 122, 1670-1680. [CrossRef]

47. Mohajernia, S.; Andryskova, P.; Zoppellaro, G.; Hejazi, S.; Kment, S.; Zboril, R.; Schmidt, J.; Schmuki, P. Influence of Ti ${ }^{3+}$ defect-type on heterogeneous photocatalytic $\mathrm{H}_{2}$ evolution activity of $\mathrm{TiO}_{2}$. J. Mater. Chem. A 2020, 8, 1432-1442. [CrossRef]

48. Wang, H.; Bu, Y.; Wu, G.; Zouc, X. The promotion of the photocatalytic nitrogen fixation ability of nitrogen vacancy-embedded graphitic carbon nitride by replacing the corner-site carbon atom with phosphorus. Dalton Tran. 2019, 48, 11724-11731. [CrossRef]

49. Yang, L.; Liu, X.; Liu, Z.; Wang, C.; Liu, G.; Li, Q.; Feng, X. Enhanced photocatalytic activity of g-C ${ }_{3} \mathrm{~N}_{4} 2 \mathrm{D}$ nanosheets through thermal exfoliation using dicyandiamide as precursor. Ceram. Int. 2018, 44, 20613-20619. [CrossRef]

50. Che, H.; Liu, L.; Che, G.; Dong, H.; Liu, C.; Li, C. Control of energy band, layer structure and vacancy defect of graphitic carbon nitride by intercalated hydrogen bond effect of $\mathrm{NO}_{3}{ }^{-}$toward improving photocatalytic performance. Chem. Eng. J. 2019, 357, 209-219. [CrossRef]

51. Dong, F.; Li, Y.H.; Wang, Z.Y. Enhanced visible light photocatalytic activity and oxidation ability of porous graphene-like g- $\mathrm{C}_{3} \mathrm{~N}_{4}$ nanosheets via thermal exfoliation. Appl. Surf. Sci. 2015, 358, 393-403. [CrossRef]

52. $\mathrm{Wu}, \mathrm{X}$.; Gao, D.; Yua, H.; Yu, J. High-yield lactic acid-mediated route for $\mathrm{g}-\mathrm{C}_{3} \mathrm{~N}_{4}$ nanosheet photocatalyst with enhanced $\mathrm{H}_{2}$-evolution performance. Nanoscale 2019, 11, 9608. [CrossRef] [PubMed]

53. Ye, C.; Li, J.-X.; Li, Z.-J.; Li, X.-B.; Fan, X.-B.; Zhang, L.-P.; Chen, B.; Tung, C.-H.; Wu, L.-Z. Enhanced driving force and charge separation efficiency of protonated $\mathrm{g}-\mathrm{C}_{3} \mathrm{~N}_{4}$ for photocatalytic $\mathrm{O}_{2}$ evolution. ACS Catal. 2015, 5, 6973-6979. [CrossRef]

54. Li, K.; Huang, Z.; Zeng, X.; Huang, B.; Gao, S.; Lu, J. Synergetic effect of $\mathrm{Ti}^{3+}$ and oxygen doping on enhancing photoelectrochemical and photocatalytic properties of $\mathrm{TiO}_{2} / \mathrm{g}-\mathrm{C}_{3} \mathrm{~N}_{4}$ heterojunctions. ACS Appl. Mater. Interfaces 2017, 9, 11577-11586. [CrossRef] [PubMed]

55. Gao, L.; Gan, W.; Qiu, Z.; Zhan, X.; Qiang, T.; Li, J. Preparation of heterostructured $\mathrm{WO}_{3} / \mathrm{TiO}_{2}$ catalysts from wood fibers and its versatile photodegradation abilities. Sci. Rep. 2017, 7, 1102. [CrossRef] [PubMed] 
56. Xu, J.; Zhang, L.; Shi, R.; Zhu, Y. Chemical exfoliation of graphitic carbon nitride for efficient heterogeneous photocatalysis. J. Mater. Chem. 2013, 1, 14766-14772. [CrossRef]

57. Na, S.; Sao, S.; Lee, H. Recent Developments of advanced $\mathrm{Ti}^{3+}$-self-doped $\mathrm{TiO}_{2}$ for efficient visible-light-driven photocatalysis. Catalysts 2020, 10, 679. [CrossRef]

58. Lu, D.; Zhang, G.; Wan, Z. Visible-light-driven $g-\mathrm{C}_{3} \mathrm{~N}_{4} / \mathrm{Ti}^{3+}-\mathrm{TiO}_{2}$ photocatalyst co-exposed $\left\{\begin{array}{lllllll}0 & 1\end{array}\right\}$ and $\left\{\begin{array}{llllll}1 & 0 & 1\end{array}\right\}$ facets and its enhanced photocatalytic activities for organic pollutant degradation and Cr(VI) reduction. Appl Surf. Sci. 2015, 358, 223-230. [CrossRef]

59. Lin, $\mathrm{H}$.; Zhao, L. Novel g- $\mathrm{C}_{3} \mathrm{~N}_{4} / \mathrm{TiO}_{2}$ nanorods with enhanced photocatalytic activity for water treatment and $\mathrm{H}_{2}$ production. J. Mater. Sci. Mater. Electron. 2019, 30, 18191-18199. [CrossRef]

60. Liu, X.; Wu, X.; Long, Z.; Zhang, C.; Ma, Y.; Hao, X.; Zhang, H.; Pan, C. Photodegradation of Imidacloprid in Aqueous Solution by Metal Free Catalyst Graphitic Carbon Nitride using An Energy-Saving Lamp. J. Agric. Food Chem. 2015, 63, 4754-4760. [CrossRef]

61. Liang, S.; Zhang, D.; Pu, X.; Yao, X.; Han, R.; Yin, J.; Ren, Z. A novel $A g_{2} \mathrm{O} / \mathrm{g}_{-} \mathrm{C}_{3} \mathrm{~N}_{4}$ p-n heterojunction photocatalysts with enhanced visible and near-infrared light activity. Sep. Purif. Technol. 2019, 210, 786-797. [CrossRef]

62. Sudhaik, A.; Raizada, P.; Singh, P.; Hosseini-Bandegharaei, A.; Thakur, V.K.; Nguyen, V.-H. Highly effective degradation of imidacloprid by $\mathrm{H}_{2} \mathrm{O}_{2}$ / fullerene decorated P-doped $\mathrm{g}-\mathrm{C}_{3} \mathrm{~N}_{4}$ photocatalyst. J. Environ. Chem. Eng. 2020, 8, 104483. [CrossRef]

63. Raizada, P.; Sudhaik, A.; Singha, P.; Hosseini-Bandegharaei, A.; Gupta, V.K.; Agarwal, S. Silver-mediated $\mathrm{Bi}_{2} \mathrm{O}_{3}$ and graphitic carbon nitride nanocomposite as all solid-state $\mathrm{Z}$ scheme photocatalyst for imidacloprid pesticide abatement from water. Desalin. Water Treat. 2019, 171, 344-355. [CrossRef]

64. Chen, M.L.; Lu, T.H.; Li, S.S. Photocatalytic degradation of imidacloprid by optimized $\mathrm{Bi}_{2} \mathrm{WO}_{6} / \mathrm{NH}_{2}-\mathrm{MIL}-88 \mathrm{~B}(\mathrm{Fe})$ composite under visible light. Environ. Sci Pollut Res. 2021. [CrossRef]

65. Zhang, T.; Zhao, D.; Wang, Y.; Chang, Y.; Zhang, D.; Tang, Y.; Pu, X.; Shao, X. Facial synthesis of a novel $\mathrm{Ag}_{4} \mathrm{~V}_{2} \mathrm{O}_{7} / \mathrm{g}_{-} \mathrm{C}_{3} \mathrm{~N}_{4}$ heterostructure with highly efficient photoactivity. J. Am. Ceram. Soc. 2019, 102, 3897-3907. [CrossRef]

66. $\mathrm{Bi}, \mathrm{X} . ; \mathrm{Yu}, \mathrm{S} . ; \mathrm{Liu}, \mathrm{E} . ; \mathrm{Liu}, \mathrm{L} . ; \mathrm{Zhang}$, K.; Zang, J.; Zhao, Y. Construction of g- $\mathrm{C}_{3} \mathrm{~N}_{4} / \mathrm{TiO}_{2}$ nanotube arrays Z-scheme heterojunction to improve visible light catalytic activity. Colloids Surf. A 2020, 603, 125193. [CrossRef]

67. Liao, G.; Li, C.; Li, X.; Fang, B. Emerging polymeric carbon nitride Z-scheme system for photocatalysis. Cell Rep. $2021,2,100355$. [CrossRef]

68. Fang, H.-B.; Luo, Y.; Zheng, Y.-Z.; Ma, W.; TaO, X. Facile large-scale synthesis of urea-derived porous graphitic carbon nitride with extraordinary visible-light spectrum Photodegradation. Ind. Eng. Chem. Res. 2016, 55, 4506-4514. [CrossRef]

69. Rana, A.G.; Minceva, M. Analysis of photocatalytic degradation of phenol with exfoliated graphitic carbon nitride and lightemitting diodes using response surface methodology. Catalysts 2021, 11, 898. [CrossRef]

70. Wang, B.; Li, L.; Chen, J.; Duan, C.; Song, J.; Wang, R.; Zhang, B. Synthesis of $\mathrm{BiOCl}_{0.5} \mathrm{I}_{0.5} / \mathrm{TiO}_{2}$ heterojunctions with enhanced visible-light photocatalytic properties. J. Nanopart. Res. 2018, 20, 175. [CrossRef] 